\title{
Author: A Ferreira-Snyman
}

LEGAL CHALLENGES RELATING TO THE COMMERCIAL USE OF OUTER SPACE, WITH SPECIFIC REFERENCE TO SPACE TOURISM

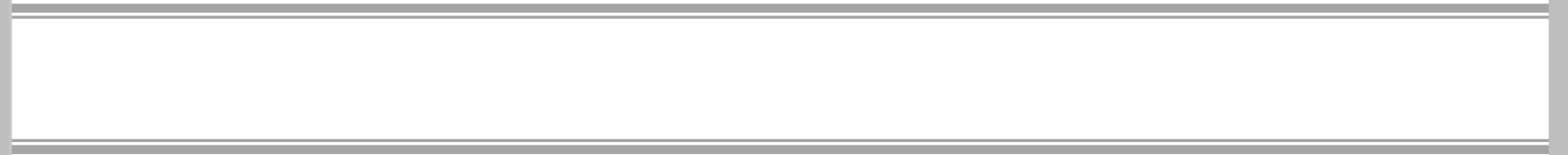

2014 VOLUME 17 No 1 


\title{
LEGAL CHALLENGES RELATING TO THE COMMERCIAL USE OF OUTER SPACE, WITH SPECIFIC REFERENCE TO SPACE TOURISM
}

\section{A Ferreira-Snyman*}

\author{
Fly me to the moon \\ Let me play among the stars \\ Let me see what spring is like \\ On Jupiter and Mars ${ }^{1}$
}

\section{Introduction}

When these words were written in 1954, three years before the launch of the first artificial satellite, Sputnik 1 in 1957, the possibility of commercial space tourist flights was at most a distant dream. The launch of Sputnik 1 introduced the Cold War space era, where space activities were intrinsically linked to the political objectives and priorities as well as to the national security or military concerns of the two superpowers, the USA and the then Soviet Union. ${ }^{2}$ Due to the strategic and political importance of space, the space powers were reluctant to allow any nongovernmental actors to explore outer space. In addition, the high cost and technological risks involved hampered private investment in outer space projects. ${ }^{3}$

Since then, the space arena has evolved to also increasingly include non-state entities, which are becoming serious actors in outer space activities themselves, ${ }^{4}$ including venturing into the space tourism market. ${ }^{5}$ Since the Russian Space Agency

Anél Ferreira-Snyman. B Juris (PUCHE), LLB (PUCHE), LLM (PUCHE), LLD (UJ). Professor, Department of Jurisprudence, Unisa. Email: Ferremp@unisa.ac.za. The research for this article was conducted in April/May 2013 by utilising the research collection of the Institute for Air and Space Law at the University of Leiden. The research was undertaken with a research grant awarded by the College Research and Innovation Committee of the College of Law at Unisa.

Lyrics from the song "Fly me to the Moon", which was composed by Bart Howard in 1954. See Songfacts date unknown http://www.songfacts.com/detail.php?id=15002.

Venet "Political Dimension" 73-74.

Walter "Privatisation and Commercialisation of Outer Space" 493.

Hofmann 2007 SAYIL 233.

Masson-Zwaan 2008 Proceedings of the International Institute of Space Law 538. For a brief exposition of the history of space tourism, see Freeland $2010 \mathrm{Melb} J$ Int'l L 7-8. 
began to take private persons to the International Space Station (ISS) in $2001^{6}$ a number of private space tourism companies have been established, especially in recent years. ${ }^{7}$ In October 2004 a company, Scaled Composites, won the Ansari $X$ Prize $^{8}$ with their space vehicle, SpaceShipOne, by flying past the altitude of 100 kilometres above the earth's surface twice within two weeks while being operated by a civilian pilot and carrying a payload equivalent to two other passengers. ${ }^{9}$ Subsequently Sir Richard Branson's company, Virgin Galactic, announced its plans to take tourists on a 90 minute long journey, costing 200000 US dollars, into suborbital space at three times the speed of sound with its spacecraft, SpaceShipTwo, launching from Spaceport America. ${ }^{10}$ SpaceShipTwo performed a successful maiden flight in 2010 and a fleet of these space vehicles is currently under construction. ${ }^{11}$ Space tourism operator, XCOR Aerospace, is developing a rocket-propelled winged vehicle, the Lynx, for passengers who wish to experience an "individualized" halfhour long sub-orbital flight by sitting alongside the pilot, and travelling to an altitude

6 To date, the following seven space tourists have travelled to the ISS on board the Russian Soyuz spacecraft: Dennis Tito (2001), Mark Shuttleworth (2002), Gregory Olsen (2005), Anousheh Ansari (2006), Charles Simonyi (2007 and 2009), Richard Garriot (2008) and Guy Laliberté (2009). See Sgrosso International Space Law 266-267; Walter "Privatisation and Commercialisation of Outer Space" 500. See further Masson-Zwaan and Freeland 2010 Acta Astronautica 1598 fn 6; Masson-Zwaan 2008 Proceedings of the International Institute of Space Law 538-539.

7 Sundahl 2009 Journal of Space Law $163 \mathrm{fn} 2$ contends that "[s]pace tourism could be said to have truly begun in 1990 when Toyohiro Akiyama, a Japanese journalist who spent almost eight days on the Russian space station, Mir, became the first private person to go into space".

8 The X PRIZE Foundation awarded the largest prize in history, namely the 10 million US dollar Ansari X Prize (sponsored by the Ansari family) to Scaled Composites for building and launching a spacecraft carrying three people, which flew $100 \mathrm{~km}$ above the earth's surface twice within a period of two weeks. The Prize is modelled on the Orteig Prize that was awarded to Charles Lindbergh in 1927 for being the first person to fly uninterrupted from New York to Paris. According to the $X$ PRIZE Foundation the spaceflight by Scaled Composites meant that "[s]paceflight was no longer the exclusive realm of government. With that single flight, and the winning of the $\$ 10$ million Ansari X PRIZE, a new industry was born". See X PRIZE Foundation $2011 \mathrm{http}: / /$ space.xprize.org/ansari-x-prize.

9 Kleiman, Lamie and Carminati Laws of Spaceflight 48; Masson-Zwaan and Freeland 2010 Acta Astronautica 1598; Freeland $2010 \mathrm{Mel}$ J J Int'l $L 2$.

10 Kleiman, Lamie and Carminati Laws of Spaceflight 49; Masson-Zwaan 2008 Proceedings of the International Institute of Space Law 539; Masson-Zwaan and Freeland 2010 Acta Astronautica 1598; Freeland 2010 Melb J Int'/ L 3.

11 Walter "Privatisation and Commercialisation of Outer Space" 501. See further Virgin Galactic 2013 http://www.virgingalctic.com/overview/spaceships. 
of 100 kilometres. ${ }^{12}$ Armadillo Aerospace has plans to develop a sub-orbital twoseater space vehicle called Hyperion. ${ }^{13}$ A capsule-styled spacecraft is being developed by Blue Origin, a company owned by Amazon.com co-founder, Jeff Bezos. ${ }^{14}$ Excalibur, a space tourism company based on the Isle of Man, plans to place tourists into orbit in the Soviet-made space capsule, Almaz, and to use the Almaz space station as a space hotel. ${ }^{15}$ Other potential space tourism operators include Rocketplane, ${ }^{16}$ which plans to offer sub-orbital flights launched out of Dubai, and SpaceX, owned by South African-born Elon Musk, which created a new type of rocket to deliver cargo on behalf of NASA to the International Space Station ${ }^{17}$ and which also plans to take private persons into space. ${ }^{18}$ The European aerospace company, EADS Astrium, has also announced its plans to provide space tourist flights for groups of four passengers to an altitude of 100 kilometres in a space vehicle named Spaceplane, which will take off and land from a runway. ${ }^{19}$

In order to launch the envisaged commercial space vehicles, the first commercial spaceport, Spaceport America, ${ }^{20}$ is currently under construction in New Mexico, while a number of further spaceports are planned in countries such as the United Arab

12 Kleiman, Lamie and Carminati Laws of Spaceflight 49-50; Masson-Zwaan 2008 Proceedings of the International Institute of Space Law 539. See further XCOR Aerospace 2013 http://xcor.com/lynx/.

13 Kleiman, Lamie and Carminati Laws of Spaceflight 50. Due to a lack of funding, the project is currently on hold. See further Citizens in Space 2013 http://www.citizensinspace.org/2013/08/armadillo-in-hibernation/. Kleiman, Lamie and Carminati Laws of Spaceflight 50. See further Blue Origin 2013 http://www.blueorigin.com/about.

15 Bigelow Aerospace in Las Vegas is building an inflatable orbiting platform to be used as a space hotel, called Sundancer, for scientific, manufacturing or leisure activities. See further Sundahl 2009 Journal of Space Law 164; Sgrosso International Space Law 268; Kleiman, Lamie and Carminati Laws of Spaceflight 52; Walter "Privatisation and Commercialisation of Outer Space" 501. Also see Excalibur Almaz 2012 http://www.excaliburalmaz.com/0002_History.html; Bigelow Aerospace 2013 http://www.bigelowaerospace.com/sundancer.php.

16 See Rocketplane Global 2013 http://www.rocketplane.com/.

17 SpaceX developed the Dragon spacecraft and Falcon 9 launch vehicle which is launched from Cape Canaveral Air Force Station in Florida. In May 2012 the Dragon became the first commercial spacecraft to successfully dock with the International Space Station. See Kleiman, Lamie and Carminati Laws of Spaceflight 53.

18 Sundahl 2009 Journal of Space Law 163-165. Also see Sgrosso International Space Law 267. See further SpaceX 2013 http://www.spacex.com.

19 Freeland 2010 Melb J Int'l L 3. Also see Howell 2013 http://www.space.com/19279-eadsastrium.html.

20 See Spaceport America 2013 http://spaceportamerica.com/. 
Emirates, Singapore, Sweden, Scotland and the Netherlands Antilles. ${ }^{21}$ Significant financial investment is also being made to develop reusable launch vehicle technology for the space tourism industry. ${ }^{22}$

Although space tourism is still in its infancy, it is estimated that the number of space tourists will reach into the hundreds (or, according to Virgin Galactic's predictions, even into the thousands) within the next few years. ${ }^{23}$ As space tourist activities increase, accidents will inevitably occur, ${ }^{24}$ which will give rise to legal questions relating to the duty of states to rescue space tourists in distress, and the liability for damages. As will be pointed out, the current outer space treaty regime, which focuses on the use of outer space by states, is to a large extent outdated and unable to deal with these questions concerning the private commercial use of space.

\section{Defining space tourism}

In a broad sense, the term "space tourism" (or "personal space flight"25) denotes "any commercial activity offering customers direct or indirect experience with space travel". ${ }^{26} \mathrm{~A}$ space tourist has been defined as "someone who tours or travels into, to,

21 Masson-Zwaan 2008 Proceedings of the International Institute of Space Law 539.

22 Freeland $2010 \mathrm{Mel} b \mathrm{~J}$ Int'l $\angle 3$.

23 Sundahl 2009 Journal of Space Law 164. In 2006, Loizou 2006 Space Policy 289 pointed out that it is estimated that within a decade there will be around a thousand sub-orbital passengers per year and a space tourism market of almost one billion US dollars by 2021. Also Freeland 2010 Melb J Int'l $L 3$ refers to optimistic estimates that suggests that "a [space] traffic level of five million space passengers per year by 2030 is achievable and represents only a conservative estimate of the known demand among potential tourists". A sophisticated space travel infrastructure is envisaged that will include "over one hundred co-orbital hotels and orbital sports centres, as well as daily scheduled lunar flights to a series of lunar orbit and lunar pole hotels". According to Walter "Privatisation and Commercialisation of Outer Space" 502 "space tourism is crystallising as a driving force for a new kind of space industry". The European Space Agency (ESA) envisages that "space tourism offers the potential for sustained progress similar to what happened in the early days of aviation". See in this regard Galvéz and Naja-Corbin 2008 ESA Bulletin 19.

Masson-Zwaan 2008 Proceedings of the International Institute of Space Law 539.

25 Loizou 2006 Space Policy 289.

26 Hobe and Cloppenburg 2004 Proceedings of the International Institute of Space Law 377; Loizou 2006 Space Policy 289. Kleiman, Lamie and Carminati Laws of Spaceflight 26 merely defines space tourism as "space travel for recreational purposes". ESA defines space tourism as "suborbital flights by privately funded and/or privately operated vehicles and the associated technology development driven by the space tourism market". See Galvéz and Naja-Corbin 2008 ESA Bulletin 19. Masson-Zwaan and Freeland 2010 Acta Astronautica 1599 however suggest that 
or through space or to a celestial body for pleasure and recreation". ${ }^{27}$ The possible space tourist activities include long-term stays in orbital facilities for research or entertainment purposes, short-term orbital or sub-orbital flights, and parabolic flights in aircraft where space tourists are exposed to weightless conditions. ${ }^{28}$

In the instance of sub-orbital spaceflight, ${ }^{29}$ orbital velocity is not achieved, as the space vehicle re-enters the earth's atmosphere after three to six minutes of microgravity has been achieved. The passengers thus experience a few minutes of weightlessness and the launch vehicle is re-used. The space vehicle is launched either horizontally or vertically and attains an altitude of around 100 kilometers. ${ }^{30}$ With orbital spaceflight, ${ }^{31}$ orbital velocity must be reached in order to allow the space vehicle to fly along the curvature of the earth without falling back to earth, making it much more energy intensive and thus also technically more difficult and more expensive than sub-orbital spaceflight. ${ }^{32}$ Depending on the atmospheric factors, an orbital spacecraft can remain in space for from a few days up to a few years. ${ }^{33}$ In the case of intercontinental rocket transport, the idea is to substantially shorten the travel time from one point of the earth to another by transiting through

"private space travel" might be a better term, for the present at least, since this kind of space travel is still reserved for very few people and can thus not yet be regarded as a mass tourist operation where large groups of people are taken on space tours. Also see Masson-Zwaan 2008 Proceedings of the International Institute of Space Law $536 \mathrm{fn} 2$.

27 O'Brien 2004 Proceedings of the International Institute of Space Law 386 as quoted by MassonZwaan and Freeland 2010 Acta Astronautica 1599.

28 Hobe and Cloppenburg 2004 Proceedings of the International Institute of Space Law 377; Hobe $2007 \mathrm{Neb} L \operatorname{Rev} 439$.

29 The term "sub-orbital spaceflight" is defined as "[s]paceflight where the spacecraft reaches outer space, but does not have sufficient energy to complete a full revolution around the Earth before reentering the atmosphere". See Kleiman, Lamie and Carminati Laws of Spaceflight 30. Also see Tronchetti 2011 Proceedings of the International Institute of Space Law 177.

30 Masson-Zwaan 2008 Proceedings of the International Institute of Space Law 538; Masson-Zwaan and Freeland 2010 Acta Astronautica 1599. Kleiman, Lamie and Carminati Laws of Spaceflight 49; Freeland 2010 Melb J Int'l L 9.

31 "Orbital spaceflight" is defined as "spaceflight where the spacecraft is launched with sufficient energy to complete at least one revolution around the earth". See Kleiman, Lamie and Carminati Laws of Spaceflight 29. Also see Tronchetti 2011 Proceedings of the International Institute of Space Law 177.

32 Masson-Zwaan 2008 Proceedings of the International Institute of Space Law 538; Masson-Zwaan and Freeland 2010 Acta Astronautica 1599; Kleiman, Lamie and Carminati Laws of Spaceflight 51; Freeland $2010 \mathrm{Melb} J$ Int'l $L 9$.

33 Kleiman, Lamie and Carminati Laws of Spaceflight 51-52. 
outer space. ${ }^{34}$ This form of transport will be specifically useful for the military, as well as for the transportation of persons and goods. There are, however, technical difficulties and safety risks associated with this form of transport. ${ }^{35}$ Because of the technological and cost demands of the latter two forms of spaceflight, most personal spaceflights currently on offer will be sub-orbital. ${ }^{36}$

Article I of the Outer Space Treaty requires that the exploration and use of outer space shall be carried out for the benefit and in the interest of all countries. Private human spaceflight may be regarded as a (mostly) recreational activity ${ }^{37}$ and, due to the high cost involved, space tourism is currently mainly reserved for the wealthy space travel enthusiast, which makes its benefit for all of mankind unclear. ${ }^{38}$ However, space tourism may have certain (long-term) social and economic advantages: ${ }^{39}$ Space tourism will most probably eventually lead to more affordable access to space, which could be seen as beneficial for all mankind. ${ }^{40}$ In addition, private human spaceflight may have certain social and economic advantages such as the development of new technologies in the area of human space travel and the

34 Masson-Zwaan 2008 Proceedings of the International Institute of Space Law 538.

35 Freeland 2010 Melb J Int'l L 10.

36 Masson-Zwaan 2008 Proceedings of the International Institute of Space Law 538; Masson-Zwaan and Freeland 2010 Acta Astronautica 1599. Companies such as Excalibur and SpaceX are, however, planning orbital space tourist flights. Space Adventures is already planning to take two space tourists beyond the low earth orbit on a circumlunar trip to the moon in the near future, using a modified Soyuz spacecraft. One ticket has already been sold for 150 million US dollars. See further Kleiman, Lamie and Carminati Laws of Spaceflight 54; Masson-Zwaan and Freeland 2010 Acta Astronautica 1599.

37 Chatzipanagiotis 2011 Proceedings of the International Institute of Space Law 56. Chatzipanagiotis describes space tourism as "a kind of extreme sport".

38 Masson-Zwaan 2008 Proceedings of the International Institute of Space Law 536. Masson-Zwaan 2008 Proceedings of the International Institute of Space Law 545 observes that "[s]afe, efficient private human access to space at reasonable cost will boost space activity, the global economy, and thus will benefit Mankind as a whole. Article 1 of the Outer Space Treaty therefore does not stand in the way of seeing space tourism as a legitimate use of space".

39 Chatzipanagiotis 2011 Proceedings of the International Institute of Space Law 56.

40 Masson-Zwaan 2008 Proceedings of the International Institute of Space Law 536. By referring to a tourism market study conducted by a US-based consultancy firm in 2002, ESA envisages that the cost of space tourist flights will gradually decrease. The projected cost of 200000 US dollars for a seat on SpaceShipTwo (with 200 people who have already made advanced payments in 2008) is expected to drop to 50000 US dollars in 2021 (with approximately 16000 interested passengers by 2021). See Galvéz and Naja-Corbin 2008 ESA Bulletin 20. Also Failat 2012 Irish Law Journal 121 points out that it is estimated that the ticket costs for sub-orbital space travel as it stood in 2012 (ranging from 60000 to 120000 dollars) will decrease by $90 \%$ in the near future. 
boosting of private investment, which could alleviate pressure on the use of public funds for near-earth space exploration. ${ }^{41}$ Moreover, if personal spaceflights also serve a scientific purpose by making it possible to carry out scientific experiments under certain space conditions, the benefit for mankind would be obvious. ${ }^{42}$

However, in order to ensure that space tourism activities indeed serve the benefit of all mankind, these activities must be undertaken in a legally regulated as well as an ethical manner. ${ }^{43}$ It is self-evident that space tourism activities will significantly add to the pollution of both the earth and the outer space environment. ${ }^{44}$ In this regard Masson-Zwaan and Freeland ${ }^{45}$ point out that it has been claimed that space tourist vehicles will eventually become the world's primary source of carbon dioxide emissions. ${ }^{46}$ An even more immediate problem is that of space debris. ${ }^{47}$ No legally binding definition of space debris has, however, been formulated yet. ${ }^{48}$ In addition, the space treaties pay very little attention to environmental issues, and the issue of space debris is not specifically addressed in the Outer Space Treaty (nor in any of the other space treaties), as these issues were not high on the agenda of the spacefaring nations at the time of the conclusion of the treaties. ${ }^{49}$ At present, the mitigation of space debris is a matter of the voluntary compliance of states with the space debris mitigation guidelines ${ }^{50}$ and national legal rules in this regard. In view of the increasing commercial use of outer space, including the planned space tourism ventures, it is imperative that this problem is addressed as a matter of urgency, as it could significantly hamper the future exploration and use of space.

Chatzipanagiotis 2011 Proceedings of the International Institute of Space Law 56.

Chatzipanagiotis 2011 Proceedings of the International Institute of Space Law 56.

For a further discussion of these ethical considerations see Freeland 2010 Melb J Int'l L 25-28.

Masson-Zwaan and Freeland 2010 Acta Astronautica 1606.

Masson-Zwaan and Freeland 2010 Acta Astronautica 1606.

In addition to the protection of the space environment from pollution, Masson-Zwaan and Freeland 2010 Acta Astronautica 1606 submit that legal regulation for the protection of so-called "heritage sites" in outer space will be needed. These areas would, for example, include the site of the first moon landing by people.

Masson-Zwaan and Freeland 2010 Acta Astronautica 1606. See further in this regard FerreiraSnyman 2012 CILSA 19-51.

Schrogl "Space and Its sustainable Uses" 65; Kim 2009 Proceedings of the International Institute of Space Law 215; Viikari Environmental Element in Space Law 32.

Lyall and Larsen Space Law 303; Viikari Environmental Element in Space Law 32.

UN Office for Outer Space Affairs 2010 http://www.iadc-online.org/index.cgi?item=documents. 


\section{Delimiting outer space}

The term "outer space" generally refers to the entire universe, in other words, any area beyond the earth's atmosphere. However, since spaceflight can be undertaken in only a very limited part of outer space, this general meaning is too broad for legal purposes. In a legal sense, "outer space" refers to that part of the universe where human activities are practically possible or feasible. ${ }^{51}$ Some activities which are based on earth are, however, intrinsically linked to outer space activities and the question remains whether space law should also be applicable to these activities or not. $^{52}$

The delimitation of outer space essentially concerns the question of where air space ends and where outer space begins. The answer to this question is significant in order to determine which activities are indeed space activities under international space law, and which activities are governed by other legal regimes. In contrast to air space which falls under the territorial sovereignty of the underlying state, international law determines that outer space is not subject to the sovereignty of any particular state. ${ }^{53}$ It may therefore be regarded in customary international law that states do not need the prior consent of other states in order to conduct activities in outer space. ${ }^{54} \mathrm{~A}$ private entity therefore does not need prior permission from any sovereign state to conduct tourist activities in outer space. As will be discussed below, the only authorisation needed is that of the launching state, which

$51 \quad$ Neger and Walter "Space Law" 238.

52 Neger and Walter "Space Law" 238-239. According to the authors these activities include those which "can be considered as facilitating access to and the return from outer space, like all kinds of launching and return facilities (spaceports as well as spacecrafts)" and those activities which "regulate the operation and control of human conduct in outer space, like all activities concerning the functioning of satellites and other outer space systems (e.g. ISS)" (Neger and Walter "Space Law" 239).

$53 \quad$ Neger and Walter "Space Law" 239.

54 In the North Sea Continental Shelf Cases (Federal Republic of Germany v Denmark; Federal Republic of Germany v Netherlands) Merits 1969 ICJ Reports 3230 it was stated by Lachs J that "[t]he first instruments that man sent into outer space traversed the airspace of States and circled above them in outer space, yet the launching States sought no permission, not did the States protest. This is how the freedom of movement into outer space, and in it, came to be established and recognized as law within a remarkably short period of time". Also see Freeland $2010 \mathrm{Mel}$ J J Int'l L 10-11. 
also has the obligation to continuously supervise the commercial activities of the private entity. ${ }^{55}$

Clear international consensus on the definition of outer space has, however, not yet been reached. ${ }^{56}$ Although some commentators are of the opinion that the demarcation of outer space would be premature or even unnecessary, the need for a well-defined border line in order to avoid uncertainties and conflict situations is selfevident. ${ }^{57}$ At present it is accepted, as a matter of customary international law, that the altitude of 100 kilometers above sea level (the so-called Von Kármán line ${ }^{58}$ ) can be considered as the legally relevant "edge of space". ${ }^{59}$ This means that activities executed and objects placed beyond 100 kilometers above sea level are space activities and space objects. Although this delimitation continues to be debated in theory, and may constantly vary as a result of the development of new technology, states often in practice refer to this boundary in their national legislation to

Freeland 2010 Melb J Int'/ L 11.

Masson-Zwaan and Freeland 2010 Acta Astronautica 1603, however, point out that the inclusion of a definition of outer space in a draft document entitled Treaty on the Prevention of the Placement of Weapons in Outer Space, the Threat or Use of Force Against Outer Space Objects (2008) initiates a move towards the development of a more widely recognised border between air space and outer space. The document, which was developed by two major space superpowers, China and Russia, and presented in 2008 at the Plenary Meeting of the United Conference on Disarmament in Geneva, defines outer space as "space beyond the elevation of approximately $100 \mathrm{~km}$ above ocean level of the Earth" (see a 1(a)). The use of the word "approximately" unfortunately still results in the definition lacking a clear and decisive indication of the borderline between air space and outer space. Also see Freeland $2010 \mathrm{Melb} J$ Int'/ L 12-13. Diederiks-Verschoor Introduction to Space Law 15. Cheng 1995 Air and Space Law 298 identifies three schools of thought on the delimitation and definition of outer space: (i) The spatialists who assert that there should logically be a legally determined delimitation of the end of national air space and the beginning of outer space. (ii) The functionalists who argue against the need for such delimitation, as the lawfulness or unlawfulness of space activities should, according to them, be determined solely by the nature of the activity or the vehicle. (iii) The you-don't-needto-know school, which also finds it unnecessary to determine the border between air space and outer space.

58 See further Neger and Walter "Space Law" 240. Lyall and Larsen Space Law 167-168; DiederiksVerschoor Introduction to Space Law 17.

Neger and Walter "Space Law" 240-241. Also see Diederiks-Verschoor Introduction to Space Law 19-20. Cheng 1995 Air and Space Law 299 explains that "[i]n absolute terms, this point may be put $94 \mathrm{~km}$ from the surface of the earth. Conservatively, the figure may be put at 100 or 110 $\mathrm{km} "$. He also points out that states may, as they have done with regard to the delimitation of the territorial sea, decide to claim a higher or lower limit, or tacitly or expressly agree on a specific border separating national air space from outer space. 
distinguish activities and objects which fall under their national air laws from others. $^{60}$

When a vehicle carrying space tourists is launched from earth (or in the air) and returns to earth, the journey will obviously involve both air and outer space. ${ }^{61}$ The delimitation of air space and outer space thus has significant implications for the issue of liability for damages caused by space tourism activities, as such liability may be premised on different legal regimes, namely either air law or space law. ${ }^{62}$ Consensus on the criteria to be used to identify the applicable legal regime is yet to be reached. Different theories have been developed in this regard. According to the spatialist approach the applicable legal regime will depend on the location of the spacecraft - thus, whether it is in air or outer space. ${ }^{63}$ However, due to the prevailing uncertainty regarding the delimitation of outer space, this theory is not of much assistance. ${ }^{64}$ The functional theory, in turn, focuses on the nature of the activity carried out. If the aerospace vehicle is designed for missions in orbit, space law will be applicable, as also when the vehicle travels through air space. ${ }^{65}$ Even if the space vehicle does not reach orbit after it has been launched, space law would still apply, since the flight would be regarded as a space activity. ${ }^{66}$ If the purpose of the activity is to connect two points on earth by flying through outer space, air law shall apply. ${ }^{67} \mathrm{~A}$ third theory proposes the creation of a specific regime by agreement

60 Neger and Walter "Space Law" 241. South Africa's Space Affairs Act 84 of 1993 defines outer space as "the space above the surface of the earth from the height at which it is in practice possible to operate an object in an orbit around the earth".

61 Freeland 2010 Melb J Int'/ L 11.

62 Hobe and Cloppenburg 2004 Proceedings of the International Institute of Space Law 377; Masson-Zwaan and Freeland 2010 Acta Astronautica 1602-1603.

63 Sgrosso International Space Law 283. According to ESA space tourism will be carried out substantially in the air space of a given country and will thus be subject to the domestic air laws. ESA, however, foresees that since space tourism should in the long term also involve travelling into space, space law may also be applicable to space tourism. See Galvéz and Naja-Corbin 2008 ESA Bulletin 23. Masson-Zwaan and Freeland 2010 Acta Astronautica 1601 submits that this implies that ESA follows a spatialist approach by regarding sub-orbital flights as an aviation activity to which air law must be applied and that outer space law would be applied only in the event of orbital space tourism. Also see Masson-Zwaan 2010 Air and Space Law 263. Sgrosso International Space Law 283-284.

65 Sgrosso International Space Law 283. Also see Lyall and Larsen Space Law 169-170; DiederiksVerschoor Introduction to Space Law 18-20.

66 Lyall and Larsen Space Law 170.

67 Sgrosso International Space Law 283. 
amongst states, in order to adapt the existing rules of air and space law to aerospace planes. ${ }^{68}$

Sgross ${ }^{69}$ finds the functional theory the most suitable to be applied to the different types of space transportation vehicles: A space shuttle, which "takes off like a rocket, orbits the Earth like a satellite and lands like an airplane" ${ }^{70}$ carries out its function in outer space and must therefore be regarded as a space object governed by international space law with regard to its registration, liability for damage and the rescue and return of astronauts and space objects. ${ }^{71}$

In contrast, supersonic space planes with the mission of transporting passengers from one point on earth to another by passing through outer space are not designed to be placed into orbit. Such a plane takes off like an airplane and might reach suborbital altitude for only a few seconds due to its technological needs. ${ }^{72}$ Since these planes have the same function as aircraft, they will be subject to the domestic air law regulations of the states over whose territory they fly, as well as to the different international air law conventions. ${ }^{73}$

In the case of multistage hybrid aerospace planes $^{74}$ (such as SpaceShipOne and SpaceShipTwo ${ }^{75}$ ) the situation is more complex, as different flight stages can be identified during the single space tourism journey. The space vehicle is attached to an aircraft and launched from the aircraft in the air. ${ }^{76}$ Different arguments have been raised with regard to the law that should apply to the journey, which takes place in both air space and outer space. On the one hand it is submitted that outer space law should apply already during the first stage, which entails transportation

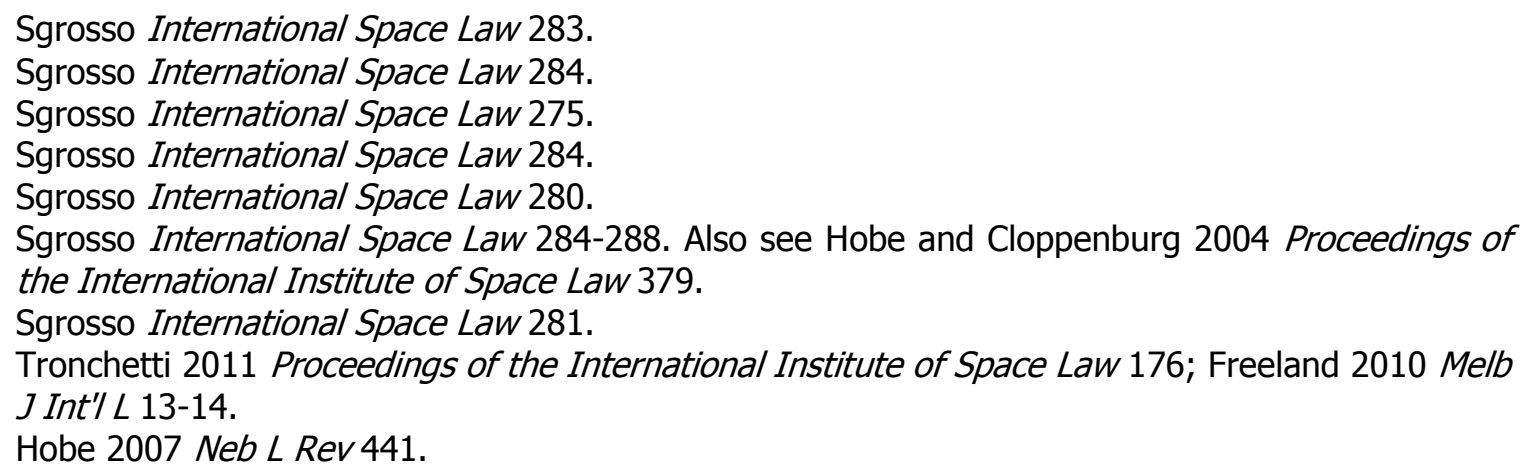


through air space, as the aircraft from which the space vehicle is launched must be regarded as a launch vehicle with the status of a space object. ${ }^{77}$ On the other hand it is argued that the aerospace plane has both the technical characteristics and function of an aircraft which carries out its function in air space, as well as that of a space object carrying out its mission in outer space. ${ }^{78}$ It is therefore contended that during the first flight stage, when the combined vehicle serves the function of transporting passengers through air space over the sovereign territories of states, it should be regarded as an aircraft governed by national and international air law. ${ }^{79}$ In the annexes to the Chicago Convention 80 "aircrafts" are defined as "all machines which can derive support in the atmosphere from the reactions of the air". ${ }^{81}$ Based on this definition, it is thus argued that during the first stage the space vehicle is merely an additional cabin that does not contribute to the propulsion, but is fully dependent on the aircraft. ${ }^{82}$ The point of separation of the aircraft and the space vehicle is regarded as the "place of destination" in terms of the Montreal Convention, making the Convention applicable to the first stage of the journey only. ${ }^{83}$ During the second stage, after the space vehicle has separated from the aircraft, it no longer

77 Sgrosso International Space Law 288.

78 Sgrosso International Space Law 281; Failat 2012 Irish Law Journal 147.

79 Sgrosso International Space Law 289. Also Hobe $2007 \mathrm{Neb} L \mathrm{Rev} 443$ finds it self-evident that air law applies to the aircraft both before and after separation from the space vehicle.

80 Convention on International Civil Aviation (1944) (Chicago Convention).

81 The current 18 annexes to the Chicago Convention can be found at Australian Government: Department of Infrastructure and Regional Development 2013 http://www.infrastructure.gov.au/aviation/international/icao/annexes/.

82 Hobe 2007 Neb L Rev 443. Hobe and Cloppenburg 2004 Proceedings of the International Institute of Space Law 379 therefore argue that sub-orbital vehicles which use rocket propulsion for thrust cannot be regarded as aircraft.

83 The Convention for the Unification of certain Rules relating to international Carriage by Air (1999) (Montreal Convention) applies to "all international carriage of persons" by aircraft (see a $1(2)$ ). In terms of the Convention carriage by aircraft will be international if "according to the agreement between the parties, the place of destination ... [is] situated within the territories of two different states parties ..." In this regard Hobe and Cloppenburg 2004 Proceedings of the International Institute of Space Law 379 submit as follows: "[I]n the case of an air launch, the Convention is applicable to the first part of the carriage, as the position where the separation takes place would constitute a 'place of destination', provided that this place of destination is located in a different State to make the carriage international." They further contend that should the separation take place over a territory not under the jurisdiction of a state party to the Montreal Convention (such as the high seas), the air carriage cannot be regarded as international and the Montreal Convention would thus not be applicable. In such an instance the liability regime will be determined by the relevant principles of private international law (Hobe and Cloppenburg 2004 Proceedings of the International Institute of Space Law 380). 
makes use of the reactions of the air and should thus be regarded as a space object $^{84}$ subject to outer space law. ${ }^{85}$

Freeland ${ }^{86}$ however, submits that although this solution is pragmatic, it is still unsatisfactory since, in the event of an accident, the applicable legal regime will depend on fortuitous circumstances, namely the specific moment that the accident occurs. ${ }^{87}$ What is also not clear from this approach is which legal regime will apply when the space vehicle returns to earth without any assistance from an aircraft. Since there is no international agreement on the boundary between air space and outer space, it would be difficult to determine when outer space should apply and when air law should apply. It seems illogical, however, to apply two legal systems (both air law and outer space law) to the journey into space, while one legal system (either air law or outer space law) is applied to the journey returning to earth.

It seems that the two-staged approach, as explained here above, results in the application of both the spatial and functional approaches. It is agreed with the submission of Masson-Zwaan and Freeland ${ }^{88}$ that the application of two legal systems during a single space tourism activity is "highly unsatisfactory and impractical". This is especially so because of the lack of international consensus on the border between air space and outer space. ${ }^{89}$ Since the development of a comprehensive multilateral treaty to regulate the complete journey of the space tourist would take a significant period of time, Masson-Zwaan and Freeland ${ }^{90}$ propose that, as an interim measure, space law should be applied to the entire sub-

There is currently uncertainty on the precise meaning of the term "space object". The Liability Convention rather vaguely defines a space object as including the "component parts of a space object as well as its launch vehicle and parts thereof". Hobe 2007 Neb $L$ Rev 443-444 regards a space object as "any object that is launched or attempted to be launched into outer space". Also see Tronchetti 2011 Proceedings of the International Institute of Space Law 178. Hobe $2007 \mathrm{Neb}$ L Rev 443. Also see Tronchetti 2011 Proceedings of the International Institute of Space Law 178; Failat 2012 Irish Law Journal 147.

86 Freeland 2010 Melb J Int'l L 14.

87 Also see Hobe and Cloppenburg 2004 Proceedings of the International Institute of Space Law 382 , who find the application of air law to only a part of the journey to be an unconvincing solution. 
orbital or orbital flight. They also base their argument on the function of the activity carried out by the vehicle, "namely that it involves a flight in(to) outer space". ${ }^{91}$ In order to clarify and supplement the current space treaties, they propose the development of a code of conduct under the auspices of the United Nations Committee on the Peaceful Uses of Outer Space (UNCOPUOS), similar to the space debris mitigation guidelines. This code, which could be modelled after air law, will also serve the purpose of harmonising different national laws concerning liability and safety issues. ${ }^{92}$

It should be pointed out that a code of conduct such as that proposed by MassonZwaan and Freeland would have the status of soft law ${ }^{93}$ and would therefore not be legally binding on states. However, as with the non-binding space debris mitigation guidelines, it could be argued that such a code would have a moral and political value, as there is an expectation that states would comply with its provisions. ${ }^{94}$ Noncompliance might be viewed in a negative light by the international partners and thus damage the political reputation of the state. ${ }^{95}$ Especially in instances where there is an urgent need for legal clarity, as is undeniably the case with space tourism, the development of a a soft law instrument offers a solution as it could be negotiated in a relatively short period of time and implemented immediately, as its application would not be dependent on ratification by states. ${ }^{96}$ It could thus furthermore be argued that soft law guidelines have a legal value as they impact on the international law-making process by providing the premise on which customary

91 Masson-Zwaan and Freeland 2010 Acta Astronautica 1603. Also see Freeland $2010 \mathrm{Melb} \mathrm{J} \mathrm{Int'/} \mathrm{L}$ 13.

92 Masson-Zwaan and Freeland 2010 Acta Astronautica 1603. Also see Masson-Zwaan 2008 Proceedings of the International Institute of Space Law 542.

93 Dugard International Law 33 describes "soft law" as "imprecise standards, generated by declarations adopted by diplomatic conferences or resolutions of international organizations, that are intended to serve as guidelines to states in their conduct, but which lack the status of 'law'". Klabbers Introduction to International Institutional Law 202 is of the opinion that the concept of soft law should be discarded mainly because it is premised on the jurisprudentially dubious notion that legal rules can be more or less binding, which is not really supported by international tribunals. Furthermore, the fact that soft law is often conceived of as informal standards-setting without any control makes it a convenient tool for the exercise of pure political power.

94 In the context of space debris mitigation see Welly 2010 Journal of Space Law 307; Tronchetti "Soft Law" 620. 
international law may develop, which may eventually lead to the conclusion of a treaty. ${ }^{97}$

As with the spatial theory, different objections can also be raised against the application of the functional theory, as proposed by Masson-Zwaan and Freeland. ${ }^{98}$ Apart from the fact that states may find it difficult to agree on the particular purpose of the activity, the location of the vehicle cannot be merely ignored. In addition, as was also pointed out earlier, there is no international agreement on the boundary between air space and outer space yet. ${ }^{99}$ In order to determine the function of the activity, it is still necessary to know where air space ends and outer space begins. It is thus clear that legal certainty regarding the applicable legal regime during a single space tourist journey cannot really be achieved until states agree on a boundary between air space and outer space. It is therefore agreed with Masson-Zwaan and Freeland, ${ }^{100}$ that a single legal regime should be applied to the entire space tourism journey. It is submitted, however, that this legal regime should not be based on the application of either the spatial or the functional theory, as both of these theories are to a lesser or greater extent dependent on the existence of a fixed boundary between air space and outer space. It is rather submitted that for the sake of legal certainty, states should agree on a specific single legal system that will apply to the entire space tourism journey - thus, to and from outer space. However, until states have agreed on the creation of a specific regime by adapting the existing rules of air and space law to space tourism activities, ${ }^{101}$ it is agreed with Masson-Zwaan and Freeland ${ }^{102}$ that existing outer space law should in the interim be applied as supplemented by a code or guidelines in order to provide clarity and legal certainty on issues such as liability and the status of space tourists. As was pointed out earlier, such a code or guidelines would not be legally binding. Alternatively, the space treaties could be supplemented by binding protocols. However, due to the

\footnotetext{
97 Tronchetti "Soft Law" 621; Welly 2010 Journal of Space Law 311. Also see Walter "Privatisation and Commercialisation of Outer Space" 503.

Lyall and Larsen Space Law 170.

Lyall and Larsen Space Law 170.

Masson-Zwaan and Freeland 2010 Acta Astronautica 1603.

Sgrosso International Space Law 289; Masson-Zwaan and Freeland 2010 Acta Astronautica 1603.

Masson-Zwaan and Freeland 2010 Acta Astronautica 1603.
} 
urgent need for legal clarity on space tourism activities, a soft law instrument seems to offer a better solution in the interim. ${ }^{103}$

\section{The legal status of space tourists}

Article $\mathrm{V}$ of the Outer Space Treaty ${ }^{104}$ describes astronauts as "envoys of mankind"105 and obliges states to provide astronauts with "all possible assistance in the event of accident, distress, or emergency landing on the territory of another State party or on the high seas". Should astronauts make such an emergency landing, they must be safely and promptly returned to the state of registry of the space vehicle. In contrast with this qualified duty of states, article $V$ places a broader duty on astronauts by obliging them to provide "all possible assistance to each other" - thus, in any place and under any circumstances. ${ }^{106}$

The Rescue Agreement of $1968,{ }^{107}$ which is based on sentiments of humanity, ${ }^{108}$ develops and gives further concrete expression to the rescue provisions in the Outer Space Treaty $^{109}$ and specifically deals with the rendering of assistance to astronauts in the event of an accident, distress or emergency landing, the prompt and safe

103 In a discussion on the duty to rescue space tourists, Sundahl 2009 Journal of Space Law 199 suggests that a "protocol could be drafted in a manner that would allow it to enter into force upon the ratification by one or two countries, thus permitting the changes to go into effect within a short period of time". This however means that the protocol would be applicable to a limited number of states only.

Treaty on Principles Governing the Activities of States in the Exploration and Use of Outer Space, Including the Moon and Other Celestial Bodies (1967) (Outer Space Treaty).

105 This does not imply, however, that astronauts have diplomatic immunity and privileges. See Sgrosso International Space Law 306; Yan 2011 Proceedings of the International Institute of Space Law 193-194. Yan points out that the description of astronauts as "envoys of mankind" may be regarded as being of symbolic value only, without any legal rights or duties attached to it. Conversely, it may be contended that since astronauts face the risks of entering an unknown world, they play an important role in the development of humankind. The fact that the obligation on states to render assistance to astronauts is placed directly after the phrase "envoys of mankind" rather seems to suggest, according to Yan, that the phrase has some legal value (Yan 2011 Proceedings of the International Institute of Space Law 194). Sundahl 2009 Journal of Space Law 167-168.

Agreement on the Rescue of Astronauts, the Return of Astronauts and the Return of Objects Launched into Outer Space (1968) (Rescue Agreement). For a concise description of the drafting history of the Rescue Agreement, specifically concerning the terminology to be used in the Agreement, see Yan 2011 Proceedings of the International Institute of Space Law 194-195.

Preamble of the Rescue Agreement.

Sundahl 2009 Journal of Space Law 168. 
return of the astronauts and the return of objects launched into outer space. ${ }^{110}$ It should be noted that the title and preamble of the Rescue Agreement refer to "astronauts", while the text of the Agreement employs the broader term "personnel of a spacecraft", which may, according to Yun, ${ }^{111}$ include astronauts, space engineers and scientists.

It is doubtful, however, that the terms "astronaut" and "space personnel" in the Rescue Agreement also include space tourists, since neither of these terms is (formally) defined in any of the outer space treaties, nor in any domestic laws. ${ }^{112}$ At the time of the drafting of the outer space treaties, space tourism was not yet envisaged and the treaties were formulated with the interests specifically of astronauts in mind. ${ }^{113}$ As Lyall and Larsen ${ }^{114}$ aptly observe, the term "[a]stronaut cannot easily fit the non-professional that is likely to enter space in the coming years whether on a limited flight or in a space-hotel".

This uncertainty leads to the question of whether or not states have a duty to rescue space tourists as passengers (as opposed to astronauts and personnel) on a spacecraft. A related question is if the duty to rescue applies only to state-sponsored missions, or to commercial spaceflights as well. ${ }^{115}$ In order to determine if a space

110 Preamble of the Rescue Agreement. The Agreement Governing the Activities of States on the Moon and Other Celestial Bodies (1979) (Moon Agreement) also contains certain rescue provisions, which are much more comprehensive than those contained in the Outer Space Treaty and the Rescue Agreement. See Sundahl 2009 Journal of Space Law 170. However, as Sundahl points out, since the Moon Agreement is restricted to the moon only, it cannot be applied to suborbital and orbital private spaceflight. In addition, the Moon Agreement has been ratified by only a small number of states (15 states to date). For ratifications, see UNOOSA 2013 http://www.oosa.unvienna.org/oosa/en/Spacelaw/treatystatus/index.html.

111 Yun 2009 J Air L \& Com 978. According to Yun, "by using a broader concept in the text, the Rescue Agreement applies to broader categories of people on board spacecraft" (Yun $2009 \mathrm{~J}$ Air $\angle \&$ Com 978). The Moon Agreement determines in a 10 that "[s]tates parties shall adopt all practicable measures to safeguard the life and health of persons on the Moon". For this purpose any person on the moon shall be regarded as an astronaut within the meaning of a $\mathrm{V}$ of the Outer Space Treaty and as part of the personnel of a spacecraft within the meaning of the Rescue Agreement.

112 Lyall and Larsen Space Law 129-130.

113 Yan 2011 Proceedings of the International Institute of Space Law 192, 199.

114 Lyall and Larsen Space Law 129.

115 Sundahl 2009 Journal of Space Law 170-171. 
tourist falls within the definition of an astronaut for legal purposes, the following elements need to be considered: training, altitude and selection. ${ }^{116}$

\subsection{Training}

It seems that, in a purely literal sense, space tourists cannot be regarded as astronauts or even personnel of a spacecraft, as they are not trained as specialists on a space mission and their main objective is one of personal pleasure, as opposed to contributing to the interest of mankind. ${ }^{117}$ This is, however, not always as simple as it seems, since different categories of space tourists can be identified and most space tourism operators require their passengers to undergo (some) training. ${ }^{118}$ The first space tourist, Dennis Tito, who visited the International Space Station (ISS) on board the Russian Soyuz spacecraft, was allowed to stay in the Russian space module only. He was regarded as a "guest cosmonaut"119 by the Russians and an "amateur astronaut" by the Americans. ${ }^{120}$ In contrast, the second space tourist on board the Soyuz, Mark Shuttleworth, agreed to certain common "rules of the road" applicable to commercial space tourists to the ISS, ${ }^{121}$ and was therefore allowed to

116 Lyall and Larsen Space Law 131. Yan 2011 Proceedings of the International Institute of Space Law 193 refers to two elements only for a person to be qualified as an astronaut: professional training and operating a spacecraft. Based on these elements, the definition of an astronaut may be formulated in a narrow or a broad sense. The author explains as follows: "[S]ome scholars construe the term in a narrow sense: only those persons who pilot or operate a spacecraft are considered as astronauts. Therefore, persons like space engineers and scientists, are not astronauts. Others construed the term in a broad way. According to them, a person who is employed on a spacecraft on a mission and who is serving some purpose in aid of the voyage, such as an engineer and a scientist capable of carrying out scientific experiments and of knowing his and his colleagues' work in the event of a replacement, shall be considered an astronaut."

117 Yun 2009 J Air L \& Com 978-979; Yan 2011 Proceedings of the International Institute of Space Law 195; Failat 2012 Irish Law Journal 123. In this regard Sgrosso International Space Law 271 points out that unlike astronauts (as envoys of mankind), space tourists "are not representatives of their State of nationality for scientific or research purposes and do not carry out any activity on behalf of national entities".

118 Failat 2012 Irish Law Journal 124.

119 Lyall and Larsen Space Law $130 \mathrm{fn} 1$ points out that the Russian term is "cosmonaut", while the Western notion is "astronaut".

120 Sgrosso International Space Law 266.

121 In 2002 the Multilateral Coordination Board of the International Space Station, which is comprised of officials from NASA and other ISS partners including Russian, Canadian, Japanese and European space agencies, agreed to certain criteria, "The Rules of the Road for Travelers to the International Space Station". These rules will apply to all travellers to the ISS, whether they are professional astronauts or spaceflight participants such as scientists, researchers, teachers, 
freely move around on the ISS. In addition, he actively participated in the space programme by carrying out certain experiments relating to genetic engineering and microgravity. ${ }^{122}$ As a result, he was considered a "non-professional astronaut", thereby giving him a higher status than that of a mere guest or visitor to the Space Station. ${ }^{123}$

All the visitors to the ISS thus far have had to undergo some training. ${ }^{124}$ However, the extent of the training required from space tourists may differ, depending on the space tourist operator and the activities undertaken in space. For example, space tourists visiting the ISS must undergo at least six weeks of training ${ }^{125}$ and some operators require additional training of space tourists who will undertake space walks. ${ }^{126}$ Conversely, Virgin Galactic offers only three days or up to one week of training to their customers. ${ }^{127}$ As a result, it is uncertain what type of training a passenger on a space vehicle must have undergone to be considered an astronaut. $^{128}$

It has been suggested by some that, since space tourists undergo some sort of training, they could be classified as personnel of a spacecraft, in order to ensure that

tourists or astronauts from non-partner space agencies. See Boyle 2002 http://www.nbcnews.com/id/3077960/ns/technology_and_science-space/t/rules-set-spacetourism-trade/; Sgrosso International Space Law 264. Sgrosso International Space Law 266.

Sgrosso International Space Law 266. Masson-Zwaan and Freeland 2010 Acta Astronautica 1599 fn 14 point out that some of the travelers to the International Space Station, including Ansari, Tito and Olsen, have expressed their disapproval of being called space tourists due to the fact that they had undergone extensive training and actively participated in activities as crew members.

Lyall and Larsen Space Law 132.

Failat 2012 Irish Law Journal 124. The Multilateral Crew Operations Panel's Principles Regarding Processes and Criteria for Selection, Assignment, Training and Certification of ISS (Expedition and Visiting) Crewmembers (2001) (MCOP Agreement) (SpaceRef 2002 http://www.spaceref.com/news/viewsr.html?pid=4578) requires that professional expedition crew members should "begin advanced training approximately 12 months before the start of increment-specific training". Visiting crew and spaceflight participants, which include space tourists, must undergo a "minimum training program [which] will be defined by the International Control Board (ITCB)".

Failat 2012 Irish Law Journal 124.

Failat 2012 Irish Law Journal 124.

Failat 2012 Irish Law Journal 125. 
they receive the humanitarian protection offered by the Rescue Agreement. ${ }^{129}$ However, others have doubted the correctness of this submission, due to the fact that personal space travel is undertaken mainly for the individual's pleasure and not to make a contribution to the public interest. ${ }^{130}$ As with the terms astronaut and envoy of mankind, the term personnel has no specifically defined meaning in outer space law. ${ }^{131}$ Hobe $^{132}$ refers in this regard to the different connotations that these terms bear: the term astronaut "has a more explorative or scientific meaning", while personnel "has a more functional meaning" and the phrase "envoy of mankind has a more humane meaning". It may therefore be argued that since space tourists do not perform functions relating to the operating of the space vehicle during their relatively short period in outer space, they cannot be considered as personnel of the spacecraft. The "profile of these passengers" is thus not in accordance with what the drafters of the Rescue Agreement intended. ${ }^{133}$

\subsection{Altitude}

The element of altitude relates to the question of how high a person must travel in a space vehicle in order to be considered an astronaut. ${ }^{134}$ This question is complicated by the fact that there is not yet international consensus on the boundary between air space and outer space. ${ }^{135}$ It is also at present uncertain whether or not participants

129 Freeland 2010 Melb J Int'/ L 14; Masson-Zwaan and Freeland 2010 Acta Astronautica 1604; Failat 2012 Irish Law Journal 125; Hobe 2007 Neb L Rev 455-456.

130 Yun 2009 J Air L \& Com 979. Failat 2012 Irish Law Journal 125 points out that "even if ... passengers and non-crew members were deemed 'personnel', it would still be uncertain whether privileges and immunities enjoyed by astronauts would be available for space tourists as it was 'not the intention of the treaty makers to cater for this group'". According to Yan 2011 Proceedings of the International Institute of Space Law 196 "[i]t is unreasonable to gather that the drafters intended to include space tourists in the category of personnel of spacecrafts in the Rescue Agreement".

131 Failat 2012 Irish Law Journal 125.

132 Hobe $2007 \mathrm{Neb} L \mathrm{Rev} 455$.

133 Hobe 2007 Neb L Rev 456.

134 Lyall and Larsen Space Law 132-133.

135 As was pointed out above, at present the altitude of $100 \mathrm{~km}$ above sea level is widely regarded as the legal boundary between air space and outer space. However, the United States regards the altitude of $80 \mathrm{~km}$ above sea level as the edge of outer space. Consequently, a person travelling higher than $80 \mathrm{~km}$, is awarded his/her so-called "astronaut wings". See in this regard Lyall and Larsen Space Law 133-134; Failat 2012 Irish Law Journal 124-125. 
in a commercial sub-orbital spaceflight, who experience only a few minutes of weightlessness, may be considered as astronauts. ${ }^{136}$

\subsection{Selection}

In order to be included in the astronaut corps of, for example, the European Space Agency (ESA) or the crew of the ISS, certain selection criteria and processes need to be complied with. ${ }^{137}$ In the case of the ESA, applicants inter alia have to show competence in relevant scientific principles, engineering or piloting skills, certain language skills, and emotional stability. In addition, medical records similar to those of pilots need to be provided during the selection process. ${ }^{138}$ The selection criteria for ISS crew members are set out in the Multilateral Crew Operations Panel (MCOP) Agreement of 2001. ${ }^{139}$ The Agreement divides crew members into "professional astronauts/cosmonauts" and "spaceflight participants" (including space tourists), which can be designated as "expedition (increment) crewmembers" and "visiting crewmembers". ${ }^{140}$ Each ISS partner applies its own selection criteria for its astronaut corps, but the other crew members listed here above must comply with the requirements as set out in the MCOP Agreement. These criteria inter alia include behavioural suitability, linguistic ability and medical requirements. ${ }^{141}$ Since space tourists visiting the ISS are regarded as spaceflight participants, they will have to comply with the criteria as set out in the MCOP Agreement. ${ }^{142}$ It is, however, still unclear whether or not space tourism operators will have set selection criteria (except for medical screening in some instances) ${ }^{143}$ which space tourists who wish to

\footnotetext{
136 Lyall and Larsen Space Law 132.

137 For ESA's criteria, see ESA 2013 http://www.esa.int/Our_Activities/Human_ Spaceflight/Astronaut_traning_requirements.

See further Lyall and Larsen Space Law $131 \mathrm{fn} 9$.

MCOP Agreement. Also see Lyall and Larsen Space Law 146 fn 62.

MCOP Agreement para III.

MCOP Agreement para IV.

142 Freeland 2010 Melb J Int'/ L 15 points out that "[t]he Agreement has not gone so far as to require these participants to sign a code of conduct - as is required for crew members of the ISS - but the inclusion of non-professional persons, such as tourists, on board space vehicles will necessitate acceptance by them of some minimum standard of care". 
undertake a shorter sub-orbital (or eventually longer orbital) spaceflights should comply with.

The above discussion of the elements relating to the definition of an astronaut clearly indicates that the current space law regime needs to be amended by a new treaty or at least supplemented by means of a protocol in order to provide clarity regarding the legal status of space tourists. ${ }^{144}$ In formulating a legal framework for space tourism it has been suggested by some commentators that the International Space Station Intergovernmental Agreement (IGA) ${ }^{145}$ and the MCOP Agreement may serve as examples to clarify the legal status of the different participants in a commercial spaceflight. ${ }^{146}$

The IGA describes crew as "qualified personnel". ${ }^{147}$ However, as was pointed out above, it is uncertain whether space tourists may be regarded as personnel on a space vehicle. Moreover, due to the limited training that a space tourist receives, it is highly doubtful if such a person has the same level of qualification as a professional crew member. ${ }^{148}$ This is also evident from the MCOP Agreement, which determines that:

Only professional astronauts/cosmonauts will be eligible to be assigned as crew commanders, pilots, flight engineers, station scientists or mission specialists in either expedition or visiting crews. Spaceflight participants will be eligible to be assigned as visiting scientists, commercial users, or tourists. Task assignments for spaceflight participants will not include ISS assembly, operations and maintenance activities. ${ }^{149}$

See in this regard Sundahl 2009 Journal of Space Law 199; Failat 2012 Irish Law Journal 129; Yun 2009 J Air L \& Com 979.

Agreement Among the Government of Canada, Governments of Member States of the European Space Agency, the Government of Japan, the Government of the Russian Federation, and the Government of the United States of America concerning Cooperation on the Civil International Space Station (1998).

Yun 2009 J Air L \& Com 980; Failat 2012 Irish Law Journal 126-127; Masson-Zwaan and Freeland 2010 Acta Astronautica 1604; Hobe 2007 Neb L Rev 457.

A 11(1). See Yun 2009 J Air L \& Com 980.

As Lyall and Larsen Space Law 128 point out: "We do not consider all those on a cruise-liner to be sailors, or passengers on aircraft to be pilots, flight engineers or cabin staff, and there is a clear parallel between such cases and touristic space-flight".

MCOP Agreement para V. Sgrosso International Space Law 270 suggests that a distinction between crew members and passengers can be made by following air law, which determines in 
As was pointed out earlier, the MCOP Agreement reached between the ISS partners, sets out who are allowed on the Space Station and clearly distinguishes between different categories of crew members. These crew members are defined as follows:

A professional astronaut or cosmonaut is an individual who has completed the official selection and has been qualified as such at the space agency of one of the ISS partners and is employed on the staff of the crew office of that agency. ${ }^{150}$

Spaceflight participants are

individuals (e.g. commercial, scientific and other programmes; crewmembers of non-partner space agencies, engineers, scientists, teachers, journalists, filmmakers or tourists) sponsored by one or more partner(s). Normally this is a temporary assignment that is covered under a short-term contract. ${ }^{151}$

The above crew members may be designated as "expedition or increment crewmembers" who are the "main crew of the ISS" and "visiting crewmembers" who "travel to and from the ISS" and who are not expedition crew members, but may either be professional astronauts/cosmonauts or spaceflight participants. ${ }^{152}$ The latter may include a visiting scientist, commercial user or tourist with specific functions. ${ }^{153}$ In this regard Hobe ${ }^{154}$ submits that it could be argued that space tourists fall under the command of the commander of the space vehicle on which they are passengers. However, their functions on the space mission are minor, if they have any at all. Therefore, whether they are regarded as crew members or not, "their subordinate function in space travel should be clearly reflected in their status". ${ }^{155}$

the Chicago Convention that crew members should have licences in order to carry out their functions.

150 MCOP Agreement para III.

151 MCOP Agreement para III.

152 MCOP Agreement para III.

153 Failat 2012 Irish Law Journal 126-127. On a domestic level, the United States' Commercial Space Launch Act of 2004 makes a distinction between "crew" and "space flight participants". See in this regard Failat 2012 Irish Law Journal 127-129.

154 Hobe 2007 Neb L Rev 458. Sundahl 2009 Journal of Space Law 168 refers to passengers on board a space vehicle as "non-crew members". 
Failat ${ }^{156}$ contends that the above Agreements relating to the ISS have "helped to develop soft law rules of a legally binding character, which appear to provide security and certainty in relation to passengers travelling to the ISS". It is submitted that this statement is not completely correct. As was pointed out earlier, soft law guidelines are not legally binding and may, at most, provide the premise on which customary international law may develop, which may lead to the conclusion of a treaty. Moreover, although these ISS Agreements may be instructive in eventually formulating the different categories of space travellers and their respective rights and duties, they do not provide legal certainty on whether or not the Rescue Agreement, as it currently reads, should also apply to space tourists. In fact, a reading of the different categories of space travelers in the MCOP Agreement shows a clear distinction between professional crew members (professional astronauts/cosmonauts) and spaceflight participants, who include space tourists. This may thus imply that the Rescue Agreement, which specifically refers to "astronauts" and "space personnel", will not be applicable to space tourists.

$\operatorname{Yan}^{157}$ points out that, for a number of reasons, non-spacefaring states especially may be unwilling to extend the provisions of the Rescue Agreement to space tourists. First, the obligation in the Rescue Agreement to provide "all possible assistance" to astronauts in distress is broader than the obligation in the Chicago Convention, which requires only that "practicable" assistance must be provided to passengers on an aircraft in distress. It is consequently debatable whether states will be willing to provide such greater assistance to space tourists, who travel to outer space for their personal interest and pleasure, like commercial aircraft passengers. ${ }^{158}$ Second, states may contend that the obligation to return space tourists to the launching state is subject to their national laws concerning foreigners and that they are therefore not obliged to return space tourists unconditionally. ${ }^{159}$ Third, although the Rescue Agreement determines that the expenses for recovering and returning a

\footnotetext{
156 Failat 2012 Irish Law Journal 127.

157 Yan 2011 Proceedings of the International Institute of Space Law 197.

158 Yan 2011 Proceedings of the International Institute of Space Law 197.

159 Yan 2011 Proceedings of the International Institute of Space Law 197.
} 
space object will be paid by the launching state, there is no similar provision relating to the expenses incurred when an astronaut is rescued and returned. Since astronauts are considered to be envoys of mankind, states are obliged to render assistance without any subsequent financial claim. ${ }^{160}$ Hence, it is again doubtful that states will be willing to incur expenses to rescue and return space tourists, who cannot be regarded as envoys of mankind. Analogous to the suggestion that an international fund should be created to compensate victims who have suffered damages caused by unidentified space debris, ${ }^{161}$ it might be contemplated to create a fund which is to be used for the rescue and return of space tourists in distress. It is unlikely, however, that states would be willing to contribute to such a fund, since space tourists are not considered to be astronauts who undertake space activities for the benefit of mankind.

It is submitted that the rationale behind the Rescue Agreement may motivate the extended application of the Agreement to space tourists, at least until a new convention or protocol on the commercial use of space has been drafted, that clearly clarifies the legal status of space tourists. Although it could be argued that the drafters of the Rescue Agreement had only astronauts in mind, ${ }^{162}$ it should also be considered that the Agreement was "prompted by sentiments of humanity". ${ }^{163}$ In view of this, it is inconceivable that in the case of an emergency only the astronauts would be rescued, without assisting the space tourists on board the space vehicle as well. ${ }^{164}$ For this reason, a broad interpretation of the Rescue Agreement is necessary. Different arguments have been raised as to how the Rescue Agreement could be interpreted in order to provide space tourists with the protection offered by the Agreement.

\footnotetext{
160 Yan 2011 Proceedings of the International Institute of Space Law 197.

161 See Sgrosso International Space Law 136; Viikari Environmental Element in Space Law 183-184.

162 Yan 2011 Proceedings of the International Institute of Space Law 199.

163 Preamble of the Rescue Agreement.

164 Masson-Zwaan and Freeland 2010 Acta Astronautica 1604; Failat 2012 Irish Law Journal 129.
} 
By employing the interpretational guidelines in the Vienna Convention, ${ }_{1}^{165}$ Sundahl ${ }^{166}$ reaches the conclusion that the duty to rescue in the outer space treaties should be interpreted broadly in order to include the rescue of space tourists. According to him the use of the term "personnel" in the text of the Rescue Agreement (as opposed to the term "astronaut") and the omission of the phrase "envoys of mankind" (as used in the Outer Space Treaty) broadens the scope of the duty to rescue, thereby including space tourists and commercial spaceflights. In terms of the lex posteriori rule this broader scope of the Rescue Agreement supersedes the narrower language of the Outer Space Treaty. ${ }^{167}$

Yan, ${ }^{168}$ in turn, proposes that a broad interpretation of the Rescue Agreement is possible with reference to article $31(3)(a)$ and (b) of the Vienna Convention. ${ }^{169}$ In terms of article 31(3)(a) states parties to the Rescue Agreement can reach an agreement that the interpretation of the terms "astronaut" and "personnel of a spacecraft" should include space tourists. Alternatively, in terms of article 31(3)(b) of the Vienna Convention, such agreement may be established through the practice of the parties in their subsequent application of the Rescue Agreement.

It is submitted, however, that by merely employing the teleological approach to treaty interpretation, the provisions of the Rescue Agreement can be extended to space tourists. In terms of this approach the treaty should be interpreted in the light

165 Vienna Convention on the Law of Treaties (1969).

166 Sundahl 2009 Journal of Space Law 174.

167 Sundahl 2009 Journal of Space Law 178. Sundahl explains as follows: "Under the lex posteriori rule in Article 30 of the Vienna Convention, the Outer Space treaty applies 'only to the extent that its provisions are compatible' with the Rescue Agreement. That the Rescue Agreement was intended to supersede the Outer Space Agreement with respect to the duty to rescue and return is clear. ... Therefore, under the operation of the lex posteriori rule, the Rescue Agreement must trump the Outer Space Treaty where the terms are inconsistent." Other authors have also suggested that the provisions of the Rescue Agreement should be extended to space tourists. See in this regard Yun $2009 \mathrm{~J}$ Air L \& Com 979.

168 Yan 2011 Proceedings of the International Institute of Space Law 198-199.

169 The article reads as follows: "There shall be taken into account, together with the context (a) any subsequent agreement between the parties regarding interpretation of the treaty or the application of its provisions; (b) any subsequent practice in the application of the treaty which establishes the agreement of the parties regarding its interpretation". 
of its object and purpose. ${ }^{170}$ As was pointed out earlier, the Rescue Agreement is based on a concern for human life. It is thus clear that the object and purpose of the treaty is to save the lives of people in distress while they are undertaking an outer space activity, irrespective of their status and their function on board the spacecraft. If space tourists were to be left in distress without any attempt by states to rescue them it would constitute a grave infringement of their rights to human dignity and life.

In order to give effect to the teleological interpretation of the Rescue Agreement, states could be requested to submit declarations indicating that the protection offered by the Agreement is also applicable to space tourists. Alternatively, states could adopt a protocol in this regard. However, since the adoption and ratification of a protocol may take time, it is proposed that in view of the urgency of the matter an advisory opinion on the interpretation of the Rescue Agreement be sought from the International Court of Justice. Although it would not be binding on states, such an authoritative opinion would at least provide legal certainty on the status of space tourists. Depending on the subsequent state practice in this regard, the duty to rescue space tourists may eventually become an erga omnes obligation, binding also on non-states parties to the Rescue Agreement.

\section{$5 \quad$ Liability}

The challenges in applying both air law and outer space law to a single space tourism journey, as was discussed earlier, are especially evident in the context of liability. In contrast with air law, which has clear and tested rules on passenger, operator and third-party liability, the outer space legal rules relating to liability are state-orientated and have not yet been interpreted by the courts. ${ }^{171}$

\footnotetext{
170 Dugard International Law 425.

171 Masson-Zwaan 2008 Proceedings of the International Institute of Space Law 541. Also see Ronan-Heath 2011 Proceedings of the International Institute of Space Law 203.
} 
Article VI of the Outer Space Treaty currently sets out the liability regime for outer space by determining that:

States Parties to the Treaty shall bear international responsibility for national activities in space, including the Moon and other celestial bodies, whether such activities are carried on by governmental agencies or by non-governmental entities, ${ }_{1}^{172}$ and for assuring that national activities are carried out in conformity with the provisions set forth in the present Treaty.

The provision furthermore prescribes that:

The activities of non-governmental entities in outer space, including the Moon and other celestial bodies, shall require authorisation and continuing supervision by the appropriate State Party to the Treaty.173

States thus bear responsibility for their own space activities, as well as for the activities carried out by non-governmental entities that launch space objects from their territories. In addition, the activities of non-governmental entities must be authorised and continuously supervised by the relevant state. This broader form of accountability in outer space law differs from the equivalent in international air law, where the state is responsible only for the regulation of the private entity, such as an airline, but not for damage caused by it. ${ }^{174}$ This provision in the Outer Space Treaty is significant, as space activities carried out by private entities are rapidly increasing. ${ }^{175}$ According to Freeland, the principles in article VI of the Outer Space Treaty have already attained the status of customary law, which binds all states. ${ }^{176}$

There are, however, a number of uncertainties with regard to the due-diligence obligations ${ }^{177}$ in article VI. Apart from the lack of clarity on the meaning of terms such as "national activities" and "appropriate state party" in the context of space

Own emphasis.

Own emphasis.

Failat 2012 Irish Law Journal 131.

Sgrosso International Space Law 110.

Freeland $2010 \mathrm{Melb} \mathrm{J}$ Int'l L 17.

Masson-Zwaan 2008 Proceedings of the International Institute of Space Law 546. 
tourism, ${ }^{178}$ it is not clear how states will implement their obligations under article VI in a uniform manner. ${ }^{179}$ Some states, for example South Africa, ${ }^{180}$ authorise private space activities by means of a statutory licensing system. In contrast, other states do not explicitly provide for a licensing system in their domestic space legislation and even a major space power, France, has for many years functioned well without such a system. ${ }^{181}$ Supervision mechanisms may, for example, include periodical reviews or audits once a licence has been granted to a private operator. However, since the meaning of the term "continuous supervision" has not been clarified, the manner and frequency of supervision is currently also left to the discretion of states. ${ }^{182}$ In addition, smaller countries that are not major space actors may lack the necessary expertise to properly evaluate the private space activities concerned. ${ }^{183}$ As a result of the diverse manner in which states may implement the generally-framed obligations in article VI, Masson-Zwaan ${ }^{184}$ stresses the need for the continuous global harmonisation of domestic space legislation through the UNCOPUOS, as well as on a regional level, for example, in Europe and in Africa. ${ }^{185}$

The international liability of a launching state is provided for as follows in article VII of the Outer Space Treaty.

Each State Party to the Treaty that launches or procures the launching of an object into outer space, including the Moon and other celestial bodies, and each State Party from whose territory or facility an object is launched, is internationally liable for damage to another State Party to the Treaty or to its natural or juridical persons

See in this regard Masson-Zwaan 2008 Proceedings of the International Institute of Space Law 542-543.

Masson-Zwaan 2008 Proceedings of the International Institute of Space Law 543.

See aa 11-14 of the Space Affairs Act 84 of 1993.

Masson-Zwaan 2008 Proceedings of the International Institute of Space Law 543. Masson-Zwaan 2008 Proceedings of the International Institute of Space Law 543. Masson-Zwaan 2008 Proceedings of the International Institute of Space Law 543-544. Masson-Zwaan 2008 Proceedings of the International Institute of Space Law 544.

Due to the socio-economic benefits associated with space exploration, a number of African states have developed modest space programmes and formulated space policies and legislation. Apart from a number of already existing national space agencies, the possible establishment of an African Space Agency is being investigated by the African Union. See in this regard Smith Mail and Guardian 13. For a further discussion on the use of outer space by developing states in Africa, see Ferreira-Snyman 2012 CILSA 44-49. 
by such object or its component parts on the earth, in air space or outer space, including the Moon and celestial bodies. ${ }^{186}$

The Outer Space Treaty thus makes provision for both the international responsibility and liability of states for outer space activities. There are, however, different scholarly opinions on how these terms should be used, and they are even sometimes used interchangeably. ${ }^{187}$

In international law, state responsibility refers to a state's responsibility for an internationally wrongful act and arises upon a breach of an international obligation (an objective fault) in instances where such a breach is attributable to the state. ${ }^{188}$ The domestic law elements for wrongfulness, namely subjective fault (culpa) and damage are thus not required for a state to incur international responsibility. ${ }^{189} \mathrm{~A}$ state commits an internationally wrongful act when it uses or allows its territory to be used in a manner that causes harm to the territory of another state or the persons or the property of that state. ${ }^{190}$ The remedies for an internationally wrongful act are restitution, satisfaction and non-repetition. ${ }^{191}$

Liability, in turn, relates to the remedying of harm irrespective of whether it has been caused by a violation of an international rule or not. ${ }^{192}$ The element of damage is thus an indispensable criterion for international liability. ${ }^{193}$ According to Van der Dunk there is, however, a partial overlap between the terms "responsibility" and "liability", as an internationally wrongful act by one state can often cause damage to

\footnotetext{
186 Own emphasis.

187 Viikari Environmental Element in Space Law 65; Failat 2012 Irish Law Journal 132.

188 See a 2 of the Draft Articles on the Responsibility of States for Internationally Wrongful Acts (Report of the International Law Commission, GA 56th Session, Suppl 10 (A/56/10) 29) (2001). Van der Dunk 1991 Proceedings of the International Institute of Space Law 363.

Dugard International Law 402.

Articles 30,31,34-37 of the Draft Articles on the Responsibility of States for Internationally Wrongful Acts (Report of the International Law Commission, GA 56th Session, Suppl 10 (A/56/10) 29) (2001). See further Van der Dunk 1991 Proceedings of the International Institute of Space Law 364; Dugard International Law 402; Failat 2012 Irish Law Journal 131-132.

192 Viikari Environmental Element in Space Law 65 fn 40.

193 Van der Dunk 1991 Proceedings of the International Institute of Space Law 364.
} 
another state, its nationals or its property. ${ }^{194}$ States could therefore theoretically be held responsible for damage simultaneously under articles VI and VII of the Outer Space Treaty, as well as under the provisions of the Liability Convention. ${ }^{195}$

The Liability Convention provides for more detailed rules in instances where damage was caused by states as a result of their space activities. Article II of the Convention makes provision for absolute liability in the instance of damage caused by a space object "on the surface of the Earth or to aircraft in flight".

Article III of the Convention furthermore determines that:

In the event of damage being caused elsewhere than on the surface of the Earth to a space object of one launching State or to persons or property on board such a space object by a space object of another launching State, the latter shall be liable only if the damage is due to its fault or the fault of persons for whom it is responsible. ${ }^{196}$

The Liability Convention thus makes provision for a two-fold liability regime: in the instance where damage is caused by a space object on the earth or to an aircraft in flight, the state shall incur absolute objective liability, which is based not on fault but on risk. The existence of damage and the causal relationship between the damage and the space object establishes liability and entitles the victim to compensation. If the damage is caused in outer space, liability shall arise if fault is proven on the part of the state or the persons for whom it is responsible. ${ }^{197}$ Thus, if a space hotel and a space vehicle carrying space tourists collide in outer space, the launching states would be held liable if fault can be proven. And if the space vehicle should fall on the territory of a non-launching state, the launching state would be held absolutely liable for damages incurred. ${ }^{198}$

\footnotetext{
194 Van der Dunk 1991 Proceedings of the International Institute of Space Law 364 points out that "in cases of transboundary environmental pollution, where the causation of damage or harm through pollution to another state's territory (and not the actual activity causing the harm) was the quintessence of the violation of an international obligation not to do so".

195 Van der Dunk 1991 Proceedings of the International Institute of Space Law 367.

196 Own emphasis.

197 Sgrosso International Space Law 112.

198 Ito 2009 Proceedings of the International Institute of Space Law 314.
} 
Contrary to air law, there are no upper limits to the amount of compensation that the launching state should pay in the case of damage. ${ }^{199}$ It may, however, be argued that since space tourists voluntarily accept the inherent risks of space travel, the liability for damage incurred during the space activity should be limited in accordance with the assumption of risk. ${ }^{200}$

Although the Liability Convention does not specifically echo the contents of article VI regarding non-governmental entities, it may be argued that the launching state must be held liable for the activities of private entities, as is the situation in nuclear law, as states will be able to comply with the obligation to use outer space for peaceful purposes only if they assume liability for all activities carried out in outer space. ${ }^{201}$

From the above exposition it is clear that the Outer Space Treaty and the Liability Convention, due to their state-centred character, ${ }^{202}$ do not make provision for the liability of private entities undertaking space activities. ${ }^{203}$ The responsibility for such activities resides with the launching state, ${ }^{204}$ which must authorise and continuously supervise the outer space activities of private entities, and which incurs liability for damage ${ }^{205}$ caused by these activities. ${ }^{206}$ t. In terms of a $1(\mathrm{a})(\mathrm{c})$ of the Liability Convention, the launching state is "(i) A State which launches or procures the launching of a space object; or (ii) A State from whose territory or facility a space object is launched". Based on this definition, Sgrosso argues that multiple launching states could be identified during the different stages of the journey: The state that launches the space vehicle from the aircraft into outer space, the state that owns the aircraft and the state that has sovereignty over the air space where the space vehicle is launched. Since there is more than one launching state, these states will jointly have to reach an agreement in terms of a II of the Convention on Registration of Objects Launched into Outer Space (1975) on which one of them will register the space object.

205 A II of the Liability Convention defines "damage" as "loss of life, personal injury or other impairment of health; or loss of damage to property of States or of persons, natural or juridical, or property of intergovernmental organisations".

Also see Freeland 2010 Melb J Int'l L 17. 
There are, however, exceptions to the liability of the launching state. The Liability Convention specifically states in article VII that it will not apply to damage caused by the space object of the launching state to:

(a) nationals of that launching state;

(b) foreign nationals during such time as they are participating in the operation of that space object from the time of its launching or at any stage thereafter until its descent or during such time as they are in the immediate vicinity of a planned launching or recovery area as the result of an invitation by that launching State.

Paragraph (a), which excludes the liability of the launching state for damages suffered by its own nationals, was initially formulated with astronauts on board a space vehicle of their state of nationality in mind. Masson-Zwaan, ${ }^{207}$ however, questions the appropriateness of this provision for paying space tourists who are nationals of the launching state.

At a first glance it seems that space tourists would not fall within the exception in paragraph (b), as they would usually not be involved in the operation of a space vehicle. ${ }^{208}$ The launching state will thus still be liable for damage caused by its space object to a space tourist. However, as was pointed out above, the legal status of space tourists is not always clear, as some private space travellers may actively participate in certain technical and scientific activities during the space mission. ${ }^{209}$ In such an instance it could be argued that the space tourist is included in the exception in paragraph (b), which means that the launching state will not be liable for damage suffered by the private space traveller. In this regard, Hobe and Cloppenburg ${ }^{210}$ are of the opinion that since space tourists put themselves at risk as

\footnotetext{
207 Masson-Zwaan 2008 Proceedings of the International Institute of Space Law 544.

208 Freeland 2010 Melb J Int'l L 15.

209 Also see Freeland 2010 Melb J Int'l $\angle 15$.

210 Hobe and Cloppenburg 2004 Proceedings of the International Institute of Space Law 380.
} 
passengers on a space vehicle, they should not benefit from the provisions of the Liability Convention. Liability must therefore be determined in terms of domestic laws. Due to the obvious importance of passengers for the success of the commercial space tourism industry, the exclusion of space tourists from the protection of the Liability Convention may be criticised. However, as private commercial space transportation evolves, state liability for these activities may become increasingly unacceptable. ${ }^{211}$

The institution of a claim for damages by a space tourist presents some challenges. Since legal action for damages suffered by individuals can be presented to the launching state only by another relevant state, space tourists (or third parties) themselves cannot claim compensation under the Liability Convention. ${ }^{212}$ It is obviously dependent on the political will of the state to institute legal proceedings on behalf of the individual - a decision which will often be influenced by diplomatic considerations. ${ }^{213}$ Alternatively, a space tourist may bring a claim under relevant domestic laws. However, there might be certain national legal limitations, for example, provisions relating to sovereign immunity ${ }^{214}$ or capped liability limits ${ }^{215}$ which could hamper such a claim. Moreover, private space tourist operators will in all probability include clauses in the service contract to limit or exclude their liability for damages suffered by the space tourist. ${ }^{216}$

211 Hobe and Cloppenburg 2004 Proceedings of the International Institute of Space Law 380.

212 Freeland 2010 Melb J Int'l L 18; Masson-Zwaan 2008 Proceedings of the International Institute of Space Law 540.

213 Freeland 2010 Melb J Int'/ $L$ 18. Freeland points out that "[t]o date no such claim has been made and it is by no means certain that a state would decide to bring such an action, unless the circumstances were of such a magnitude that it would be politically expedient to do so". Also see Masson-Zwaan and Freeland 2010 Acta Astronautica 1604.

214 Freeland 2010 Melb J Int'/ L 18. Also see Masson-Zwaan and Freeland 2010 Acta Astronautica 1605.

215 Dempsey 2011 Proceedings of the International Institute of Space Law 173-174 points out that certain states have already capped the liability of private permit or certificate holders in order to enable their nationals to engage in space activities and to protect private investors from loss.

216 Freeland $2010 \mathrm{Melb}$ J Int'l L 18. As Freeland points out, the enforceability of these provisions will obviously be subject to the relevant national laws. For example, under South African law a private company will not be able to exclude its own negligent behaviour contractually, in order to escape liability. Also see Failat 2012 Irish Law Journal 144-146; Sgrosso International Space Law 293; Masson-Zwaan and Freeland 2010 Acta Astronautica 1605. Masson-Zwaan 2008 Proceedings of the International Institute of Space Law $544 \mathrm{fn} 23$ contends that it is doubtful 
Due to the growing number of private space operators, it is self-evident that states would also seek to limit or exclude their liability for the actions of these private entities. A number of domestic systems have already adopted space-related legislation. ${ }^{217}$ In order to escape the financial liability for damages suffered by space tourists, these national laws may in some instances provide that the launching state can recover the amount of damages for which it is internationally liable from the private launching operator. ${ }^{218}$ Some states already oblige private actors engaging in space activities to indemnify the state should it become liable for damages. ${ }^{219}$

A number of states also already require private companies who have launch and operational certificates or permits to obtain the necessary insurance to cover their space objects and launch facilities, as well as third party and product liability. ${ }^{220}$ Private companies engaging in space tourism will thus most probably also in future have to acquire the necessary insurance to indemnify them in instances of claims by states to recover the damages suffered by space tourists and third parties. ${ }^{221}$ It is,

that the legal representative of a deceased space tourist will be bound by a letter in which the space tourists gave his/her so-called informed consent to waive the right to claim damages.

The National Space Law Database of the United Nations Office for Outer Space Affairs lists the following countries that have adopted space legislation: Argentina; Australia; Austria; Belgium; Brazil; Canada; Chile; China; France; Germany; Japan; Kazakhstan; the Netherlands; Norway; Republic of Korea; Russian Federation; South Africa; Spain; Sweden; Ukraine; United Kingdom of Great Britain and Northern Ireland; United States of America. See UN Office for Outer Space Affairs date unknown http://www.oosaunvienna.org/oosa/en/SpaceLaw/national/stateindex.html. Other countries with national policies on outer space include Morocco, Tunisia, and Algeria. See Van Wyk 2008 African Skies 91-92. Also see Freeland 2010 Melb J Int'l L 17 fn 74, who points out that "there is no doubt that the development of the a significant body of domestic legislation represents one of the real 'growth areas' of space law".

218 Hobe and Cloppenburg 2004 Proceedings of the International Institute of Space Law 383. See further in this regard Freeland 2010 Melb J Int'l $L 17 \mathrm{fn} 75$, who refers to relevant sections of the Australian Space Activities Act of 1998. Also see Walter "Privatisation and Commercialisation of Outer Space" 505. The South African Space Affairs Act determines in s 11 that a person can perform activities, including any launching from the territory of the Republic, only in terms of a licence issued by the South African Council for Space Affairs. In terms of s 1 (1)(a) such a licence may contain conditions regarding the liability of the licensee for damages and the security to be provided by the licensee for such damages. Subs (2) further sets out the conditions which may be contained in the licence.

219 See further Dempsey 2011 Proceedings of the International Institute of Space Law 171 for a discussion of these indemnity provisions in different jurisdictions.

220 See further Dempsey 2011 Proceedings of the International Institute of Space Law 172-173 for a discussion of the different national provisions in this regard.

221 Sgrosso International Space Law 293. 
however, at this stage doubtful that the existing space insurance industry ${ }^{222}$ will have the capacity or even the willingness to insure space tourism ventures, especially due to the high risks involved. ${ }^{223}$ In view of the fact that individuals are already acquiring seats on commercial spaceflights, the urgent need for a new space tourism insurance model in order to assess the unique risks involved and to ensure the payment of compensation is self-evident. ${ }^{224}$

From the above discussion it is clear that the current outer space legal regime does not adequately address the unique challenges relating to liability for damages suffered by space tourists. Liability issues are therefore increasingly regulated in national space legislation, which unfortunately exacerbates the international legal uncertainty in this regard. ${ }^{225}$ It has therefore been suggested by some commentators that the relevant provisions of the air law treaties, in the form of the Warsaw, ${ }^{226}$ Montrea ${ }^{27}$ and Rome $^{228}$ Conventions, may be instructive in formulating uniform legal rules relating to liability arising from space tourism activities. Specifically the provisions on carrier liability, passenger liability, limits to liability, and third party liability may provide a valuable framework for the creation of such a legal regime. ${ }^{229}$ It should be noted, however, that due to the unique characteristics of and

222 Freeland $2010 \mathrm{Melb} \mathrm{J} \mathrm{Int'/} L 20$ points out that there is already a well-established space insurance industry that offers insurance cover for launch and in-orbit operations of both government and commercial satellites.

223 Freeland $2010 \mathrm{Melb}$ J Int'l L 20. Also see Ronan-Heath 2011 Proceedings of the International Institute of Space Law 208, who points out that insurers are for a number of reasons currently unable to assess the risk and calculate appropriate premiums for the space tourism industry.

224 See in this regard Freeland $2010 \mathrm{Melb} J \mathrm{Int}^{\prime} / \mathrm{L} 20$. See further, on space insurance, Yun $2009 \mathrm{~J}$ Air L \& Com 969-972; Chatzipanagiotis 2011 Proceedings of the International Institute of Space Law 54; Failat 2012 Irish Law Journal 144-145.

225 Freeland 2010 Melb J Int'/ L 18.

226 Convention for the Unification of Certain Rules relating to International Carriage by Air (1929) (Warsaw Convention).

227 Convention for the Unification of certain Rules relating to international Carriage by Air (1999) (Montreal Convention).

228 Convention on Damage caused by Foreign Aircraft to Third Parties on the Surface (1952) (Rome Convention).

229 It is beyond the scope of this article to discuss these specific air law provisions further. For a more detailed discussion on the relevance of these provisions see Masson-Zwaan 2008 Proceedings of the International Institute of Space Law 545-546; Hobe and Cloppenburg 2004 Proceedings of the International Institute of Space Law 378-383; Yun 2009 J Air L \& Com 967969; Ronan-Heath 2011 Proceedings of the International Institute of Space Law 202-211; Freeland 2010 Melb J Int'l L 19. 
risks involved in space tourism, the air law model cannot merely be extended to space tourism, ${ }^{230}$ but will have to be adapted in order to answer to the very specific needs of this new space travelling industry. ${ }^{231}$

\section{The way forward?}

It should be clear from the above exposition that the current space treaties are to a large extent outdated and that they cannot adequately deal with the unique legal challenges presented by the rapidly developing space tourism industry. This is furthermore exacerbated by the fact that the outer space legal framework is very fragmented - consisting of treaties, UN principles and guidelines, regional regulations and intergovernmental agreements, as well as national guidelines and legislation.

In order to ensure that space tourism is indeed to the benefit of all mankind, it is imperative that clear international legal rules relating to space tourism are formulated, where standards are set for the authorisation and supervision of these activities, and the interests of states, passengers and private actors are balanced as far as possible.

Different suggestions have been made by commentators on the manner in which legal rules dealing with aspects relating to space tourism should be formulated and adopted. Some have suggested the creation and adoption of a completely new binding legal framework based on the principles of both air and space law. ${ }^{232}$ Conversely, others have suggested the adoption of protocols to clarify the uncertainties in the existing space treaties. ${ }^{233}$ Suggestions for the creation of soft law instruments in the form of non-binding codes and guidelines have also been

\footnotetext{
230 Hobe and Cloppenburg 2004 Proceedings of the International Institute of Space Law 382.

231 Freeland 2010 Melb J Int'/ $\angle 18$.

232 See, for example, Yun $2009 \mathrm{~J}$ Air L \& Com 982. In this regard Hobe and Cloppenburg 2004 Proceedings of the International Institute of Space Law 383 ask if the development of "a uniform legal aerospace regime" can be identified.

233 See, for example, Sundahl 2009 Journal of Space Law 199.
} 
advanced. ${ }^{234}$ Ideally, a legal instrument that will be binding on signatory states should be adopted to deal with the unique legal questions posed by space tourism. However, in view of the urgent need to address these legal questions and the consequent lack of time to negotiate a binding legal instrument, it is submitted that as an interim measure soft law guidelines should be developed in relation to space tourism in order to provide a framework for the eventual creation of a consolidated and binding legal instrument on all aspects relating to the use and exploration of outer space. In this regard, the United Nations Convention on the Law of the Sea could serve as a valuable example. ${ }^{235}$ In order to mediate the fragmented nature of the current outer space legal regime, states should be encouraged to formulate their national (and regional) space legislation in accordance with these soft law guidelines.

In the words of Colin B Picker, ${ }^{236}$ "technology operates as an invisible hand on international law, guiding and shaping its development." However, it is clear that the current international outer space law regime is significantly underdeveloped in relation to outer space technology. It is therefore imperative that an international dialogue on space tourism is facilitated under the auspices of the UNCOPUOS to address the legal challenges as illuminated in this contribution.

See, for example, Masson-Zwaan and Freeland 2010 Acta Astronautica 1603.

United Nations Convention on the Law of the Sea (1982).

Picker 2001/2002 Cardozo L Rev 201. 


\section{BIBLIOGRAPHY}

\section{Literature}

Chatzipanagiotis 2011 Proceedings of the International Institute of Space Law

Chatzipanagiotis $M$ "The impact of liability rules on the development of private commercial human spaceflight" 2011 Proceedings of the International Institute of Space Law: 54 ${ }^{\text {th }}$ Colloquium on the Law of Outer Space 52-62

Cheng 1995 Air and Space Law

Cheng B "International responsibility and liability for launch activities" 1995 Air and Space Law 297-310

Dempsey 2011 Proceedings of the International Institute of Space Law

Dempsey PS "Liability for damage caused by space objects under international and national law" 2011 Proceedings of the International Institute of Space Law: $54^{\text {th }}$ Colloquium on the Law of Outer Space 165-175

Diederiks-Verschoor Introduction to Space Law

Diederiks-Verschoor IHP An Introduction to Space Law $3^{\text {rd }}$ ed (Kluwer Law Alphen aan den Rijn 1999)

Dugard International Law

Dugard J International Law: $A$ South African Perspective $4^{\text {th }}$ ed (Juta Cape Town 2011)

Failat 2012 Irish Law Journal

Failat YA "Space tourism: A synopsis on its legal challenges" 2012 Irish Law Journal $120-151$ 
Ferreira-Snyman 2012 CILSA

Ferreira-Snyman A "The environmental responsibility of states for space debris and the implications for developing countries in Africa" 2012 CILSA 1951

Freeland 2010 Melb J Int'/ L

Freeland S "Fly me to the moon: How will international law cope with commercial space tourism?" 2010 Melb J Int'l L 1-29

Galvéz and Naja-Corbin 2008 ESA Bulletin

Galvéz A and Naja-Corbin G "Space Tourism: ESA's View on Private Suborbital Spaceflights" 2008 ESA Bulletin Aug 19-25

Hobe $2007 \mathrm{Neb} L \mathrm{Rev}$

Hobe S "Legal aspects of space tourism" $2007 \mathrm{Neb} L \operatorname{Rev} 377-385$

Hobe and Cloppenburg 2004 Proceedings of the International Institute of Space Law Hobe S and Cloppenburg J "Toward a new aerospace convention? - Selected legal issues of 'space tourism'" 2004 Proceedings of the International Institute of Space Law: $47^{\text {th }}$ Colloquium on the Law of Outer Space 377-383

Hofmann 2007 SAYIL

Hofmann M "Environmental criteria as condition for space activities of nonentities?" 2007 SAYIL 233-246

Ito 2009 Proceedings of the International Institute of Space Law

Ito $A$ "The advent of a new era of commercial space tourism and associated legal problems" 2009 Proceedings of the International Institute of Space Law: $52^{\text {nd }}$ Colloquium on the Law of Outer Space 312-319 
Kim 2009 Proceedings of the International Institute of Space Law

Kim DH "Legal problems concerning space debris and Liability Convention" 2009 Proceedings of the International Institute of Space Law: $52^{\text {nd }}$ Colloquium on the Law of Outer Space 210-220

Klabbers Introduction to International Institutional Law

Klabbers J An Introduction to International Institutional Law $2^{\text {nd }}$ ed (Cambridge University Press Cambridge 2009)

Kleiman, Lamie and Carminati Laws of Spaceflight

Kleiman MJ, Lamie JK and Carminati M-V The Laws of Spaceflight: A Guidebook for New Space Lawyers (American Bar Association Chicago 2012)

Loizou 2006 Space Policy

Loizou J "Turning space tourism into commercial reality" 2006 Space Policy $289-290$

Lyall and Larsen Space Law

Lyall F and Larsen PB Space Law: A Treatise (Ashgate Surrey 2009)

Masson-Zwaan 2008 Proceedings of the International Institute of Space Law Masson-Zwaan T "Article VI of the Outer Space Treaty and private human access to space" 2008 Proceedings of the International Institute of Space Law: $51^{\text {st }}$ Colloquium on the Law of Outer Space 536-546

Masson-Zwaan 2010 Air and Space Law

Masson-Zwaan $T$ "Regulation of space tourism in Europe: A role for EU/EASA?" 2010 Air and Space Law 263-272

Masson-Zwaan and Freeland 2010 Acta Astronautica Masson-Zwaan $\mathrm{T}$ and Freeland $\mathrm{S}$ "Between heaven and earth: Legal challenges of human space travel" 2010 Acta Astronautica 1597-1607 
Neger and Walter "Space Law"

Neger $\mathrm{T}$ and Walter E "Space Law - An Independent Branch of the Legal System" in Brünner C and Soucek A (eds) Outer Space in Society, Politics and Law (Springer-Verlag Vienna 2011) 234-245

O'Brien 2004 Proceedings of the International Institute of Space Law

O'Brien Z "Liability for injury, loss or damage to the space tourist" 2004 Proceedings of the International Institute of Space Law: $47^{\text {th }}$ Colloquium on the Law of Outer Space 386-396

Picker 2001/2002 Cardozo L Rev

Picker CB "A view from 40,000 feet: International law and the invisible hand of technology" 2001/2002 Cardozo L Rev 149-219

Ronan-Heath 2011 Proceedings of the International Institute of Space Law

Ronan-Heath C "A new international convention to govern liability in relation to commercial space tourism - is it really necessary?" 2011 Proceedings of the International Institute of Space Law: $54^{\text {th }}$ Colloquium on the Law of Outer Space 202-211

Schrogl "Space and Its Sustainable Uses"

Schrogl K-U "Space and Its Sustainable Uses" in Brünner C and Soucek A (eds) Outer Space in Society, Politics and Law (Springer-Verlag Vienna 2011) 604-618

Sgrosso International Space Law

Sgrosso GC International Space Law (LoGisma Vicchio 2011)

Smith Mail and Guardian

Smith D "Sudan wants Africa to reach for the stars" Mail and Guardian (14 September 2012) 13 
Sundahl 2009 Journal of Space Law

Sundahl MJ "The duty to rescue space tourists and return private spacecraft" 2009 Journal of Space Law 163-200

Tronchetti 2011 Proceedings of the International Institute of Space Law

Tronchetti F "Regulating sub-orbital flights traffic: Using air traffic control as a model?" 2011 Proceedings of the International Institute of Space Law: $54^{\text {th }}$ Colloquium on the Law of Outer Space 176-186

Tronchetti "Soft Law"

Tronchetti F "Soft Law" in Brünner C and Soucek A (eds) Outer Space in Society, Politics and Law (Springer-Verlag Vienna 2011) 619-637

Van der Dunk 1991 Proceedings of the International Institute of Space Law Van der Dunk F "Liability versus responsibility in space law: Misconception or misconstruction?" 1991 Proceedings of the International Institute of Space Law: $34^{\text {th }}$ Colloquium on the Law of Outer Space 363-368

Van Wyk 2008 African Skies

Van Wyk J-A "Overview of the implementation status of the five United Nations treaties on outer space in African countries" 2008 African Skies/Cieux Africains 90-98

Venet "Political Dimension"

Venet C "The Political Dimension" in Brünner C and Soucek A (eds) Outer Space in Society, Politics and Law (Springer-Verlag Vienna 2011) 73-91

Viikari Environmental Element in Space Law

Viikari L The Environmental Element in Space Law - Assessing the Present and Charting the Future (Martinus Nijhoff Leiden 2008) 
Welly 2010 Journal of Space Law

Welly ND "Enlightened state interest - A legal framework for protecting the common heritage of mankind from Hardinian tragedy" 2010 Journal of Space Law 273-313

Walter "Privatisation and Commercialisation of Outer Space"

Walter E "The Privatisation and Commercialisation of Outer Space" in Brünner C and Soucek A (eds) Outer Space in Society, Politics and Law (SpringerVerlag Vienna 2011) 493-518

Yan 2011 Proceedings of the International Institute of Space Law

Yan L "Does the Rescue Agreement apply to space tourists" 2011 Proceedings of the International Institute of Space Law: $54^{\text {th }}$ Colloquium on the Law of Outer Space 193-192-201

Yun $2009 \mathrm{~J}$ Air L \& Com

Yun $Z$ "A legal regime for space tourism: Creating legal certainty in outer space" 2009 J Air L \& Com 959-982

\section{Case law}

North Sea Continental Shelf Cases (Federal Republic of Germany v Denmark; Federal Republic of Germany $v$ Netherlands) Merits 1969 ICJ Reports 3

\section{Legislation}

\section{Australia}

Australian Space Activities Act of 1998

\section{South Africa}

Space Affairs Act 84 of 1993 


\section{United States of America}

Commercial Space Launch Act of 2004

\section{International instruments}

Agreement Among the Government of Canada, Governments of Member States of the European Space Agency, the Government of Japan, the Government of the Russian Federation, and the Government of the United States of America concerning Cooperation on the Civil International Space Station (1998)

Agreement Governing the Activities of States on the Moon and Other Celestial Bodies (1979) (Moon Agreement)

Agreement on the Rescue of Astronauts, the Return of Astronauts and the Return of Objects Launched into Outer Space (1968) (Rescue Agreement)

Convention for the Unification of Certain Rules relating to International Carriage by Air (1929) (Warsaw Convention)

Convention for the Unification of certain Rules relating to international Carriage by Air (1999) (Montreal Convention)

Convention on Damage caused by Foreign Aircraft to Third Parties on the Surface (1952) (Rome Convention)

Convention on International Civil Aviation (1944) (Chicago Convention)

Convention on Registration of Objects Launched into Outer Space (1975)

Draft Articles on the Responsibility of States for Internationally Wrongful Acts

(Report of the International Law Commission, GA $56^{\text {th }}$ Session, Suppl 10 (A/56/10) 29) (2001)

Multilateral Crew Operations Panel's Principles Regarding Processes and Criteria for

Selection, Assignment, Training and Certification of ISS (Expedition and Visiting) Crewmembers (2001) (MCOP Agreement)

Treaty on Principles Governing the Activities of States in the Exploration and Use of Outer Space, Including the Moon and Other Celestial Bodies (1967) (Outer Space Treaty)

Treaty on the Prevention of the Placement of Weapons in Outer Space, the Threat or Use of Force against Outer Space Objects (2008) 
United Nations Convention on the Law of the Sea (1982)

Vienna Convention on the Law of Treaties (1969)

\section{Internet sources}

Australian Government: Department of Infrastructure and Regional Development 2013 http://www.infrastructure.gov.au/aviation/international/icao/annexes/ Australian Government: Department of Infrastructure and Regional Development 2013 Annexes to the Chicago Convention http://www.infrastructure.gov.au/aviation/international/icao/annexes/ accessed 4 September 2013

Bigelow Aerospace 2013 http://www.bigelowaerospace.com/sundancer.php accessed Bigelow Aerospace 2013 Next Generation Commercial Space Stations: Sundancer http://www.bigelowaerospace.com/sundancer.php accessed 3 September 2013

Blue Origin $2013 \mathrm{http}: / / w w w . b l u e o r i g i n . c o m / a b o u t$

Blue Origin 2013 About Blue Origin: Reliable, Cost Effective Human Access to Space http://www.blueorigin.com/about accessed 3 September 2013

Boyle 2002 http://www.nbcnews.com/id/3077960/ns/technology_and_sciencespace/t/rules-set-space-tourism-trade/Boyle A 2002 Rules Set for Space Tourism Trade: Rascals Need Not Apply for Space Station Flights http://www.nbcnews.com/id/3077960/ns/technology_and_sciencespace/t/rules-set-space-tourism-trade/ accessed 25 June 2013

Citizens in Space 2013 http://www.citizensinspace.org/2013/08/armadillo-inhibernation/

Citizens in Space 2013 Armadillo in Hibernation http://www.citizensinspace.org/2013/08/armadillo-in-hibernation/ accessed 3 September 2013 
ESA 2013

http://www.esa.int/Our_Activities/Human_Spaceflight/Astronaut_traning_requ irements European Space Agency 2013 Astronauts: Human Spaceflight and Exploration - Astronaut Training Requirements http://www.esa.int/Our_ Activities/Human_Spaceflight/Astronaut_traning_requirements accessed 21 June 2013

Excalibur Almaz 2012 http://www.excaliburalmaz.com/0002_History.html Excalibur Almaz 2012 History of Excalibur Almaz http://www.excaliburalmaz.com/0002_History.html accessed 3 September 2013

Howell 2013 http://www.space.com/19279-eads-astrium.html

Howell E 2013 Astrium: Spaceplane Planned for Space Tourism http://www.space.com/19279-eads-astrium.html accessed 3 September 2013

Rocketplane Global 2013 http://www.rocketplane.com/

Rocketplane Global 2013 The Space Experience http://www.rocketplane.com/ accessed 3 September 2013

Songfacts date unknown http://www.songfacts.com/detail.php?id=15002

Songfacts date unknown Fly me to the Moon by Frank Sinatra http://www.songfacts.com/detail.php?id=15002 accessed 3 April 2013

Spaceport America 2013 http://spaceportamerica.com/

Spaceport America 2013 Welcome to Spaceport America http://spaceportamerica.com/ accessed 3 September 2013

SpaceRef 2002 http://www.spaceref.com/news/viewsr.html?pid=4578 SpaceRef 2002 Principles Regarding Processes and Criteria for Selection, Assignment, Training and Certification of ISS (Expedition and Visiting) 
Crewmembers http://www.spaceref.com/news/viewsr.html?pid=4578 accessed 21 June 2013

SpaceX 2013 http://www.spacex.com SpaceX 2013 SpaceX Designs, Manufactures and Launches Advanced Rockets and Spacecraft http://www.spacex.com accessed 3 September 2013

UN Office for Outer Space Affairs date unknown http://www.oosaunvienna.org/oosa/en/SpaceLaw/national/state-index.html UN Office for Outer Space Affairs date unknown National Space Law Database http://www.oosaunvienna.org/oosa/en/SpaceLaw/national/state-index.html accessed 17 August 2013

UN Office for Outer Space Affairs 2010 http://www.iadconline.org/index.cgi?item=documents UN Office for Outer Space Affairs 2010 Space Debris Mitigation Guidelines of the Committee of the Peaceful Uses of Outer Space http://www.iadconline.org/index.cgi?item=documents accessed 21 June 2013

UNOOSA

http://www.oosa.unvienna.org/oosa/en/Spacelaw/treatystatus/index.html UNOOSA 2013 Status of International Agreements Relating to Activities in Outer Space http://www.oosa.unvienna.org/oosa/en/Spacelaw/treatystatus/ index.html accessed 3 September 2013

Virgin Galactic 2013 http://www.virgingalctic.com/overview/spaceships Virgin Galactic 2013 Spaceships: Virgin Galactic's Vehicles http://www.virgingalctic.com/overview/spaceships accessed 2 September 2013 
X PRIZE Foundation $2011 \mathrm{http}: / /$ space.xprize.org/ansari-x-prize

X PRIZE Foundation 2011 Ansari X PRIZE http://space.xprize.org/ansari-xprize accessed 20 June 2013

XCOR Aerospace 2013 http://xcor.com/lynx/

XCOR Aerospace 2013 About Lynx http://xcor.com/lynx/ accessed 3 September 2013

\section{LIST OF ABBREVIATIONS}

Cardozo L Rev Cardozo Law Review

CILSA

Comparative and International Law Journal of Southern Africa

ESA

European Space Agency

IGA

International Space Station Intergovernmental Agreement

ISS

International Space Station

J Air L \& Com

Journal of Air Law and Commerce

MCOP

Multilateral Crew Operations Panel

Melb J Int'I L

Melbourne Journal of International Law

Neb L Rev

Nebraska Law Review

SAYIL

South African Yearbook of International Law

UN

United Nations

UNCOPUOS

United Nations Committee on the Peaceful Uses of Outer Space

UNOOSA

United Nations Office for Outer Space Affairs 